\title{
Impacts of Global Change on Mediterranean Forests and Their Services
}

\author{
Josep Peñuelas 1,2,* (D) Jordi Sardans 1,2 , Iolanda Filella 1,2 , Marc Estiarte 1,2 , Joan Llusià 1,2, \\ Romà Ogaya ${ }^{1,2}$, Jofre Carnicer 1,2,3 (i), Mireia Bartrons 2,4 (i), Albert Rivas-Ubach 1,2, \\ Oriol Grau ${ }^{1,2}$, Guille Peguero ${ }^{1,2}$ (1) , Olga Margalef ${ }^{1,2}$, Sergi Pla-Rabés ${ }^{1,2}$, \\ Constantí Stefanescu 1,2,5, Dolores Asensio ${ }^{1,2}$, Catherine Preece 1,2 (1), Lei Liu 1,2, \\ Aleixandre Verger ${ }^{1,2}$, Adrià Barbeta ${ }^{1,2,6}$, Ander Achotegui-Castells ${ }^{1,2}$, \\ Albert Gargallo-Garriga ${ }^{1,2}$, Dominik Sperlich ${ }^{7}$, Gerard Farré-Armengol 1,2, \\ Marcos Fernández-Martínez ${ }^{1,2}$ (1) , Daijun Liu ${ }^{1,2}$, Chao Zhang ${ }^{1,2}$ (1) , Ifigenia Urbina ${ }^{1,2}$,
} Marta Camino-Serrano ${ }^{2}$, Maria Vives-Ingla ${ }^{1,2}$ (D) , Benjamin D. Stocker ${ }^{1,2}$, Manuela Balzarolo ${ }^{1,2}$, Rossella Guerrieri ${ }^{1,2}$, Marc Peaucelle ${ }^{1,2}$, Sara Marañón-Jiménez ${ }^{1,2}$ () , Kevin Bórnez-Mejías ${ }^{1,2}$, Zhaobin Mu ${ }^{1,2}$, Adrià Descals ${ }^{1,2}$, Alejandro Castellanos ${ }^{2,8}$ and Jaume Terradas ${ }^{1,2}$

1 CSIC, Consejo Superior de Investigaciones Científicas,, Unitat d'Ecologia Global CREAF-CSIC-UAB, 08193 Bellaterra, Catalonia, Spain; j.sardans@creaf.uab.cat (J.S.); iola@creaf.uab.cat (I.F.); m.estiarte@creaf.uab.cat (M.E.); j.llusia@creaf.uab.cat (J.L.); r.ogaya@creaf.uab.cat (R.O.); jofre@creaf.uab.cat (J.C.); a.rivas@creaf.uab.cat (A.R.-U.); o.grau@creaf.uab.cat (O.G.); guille.peguero@creaf.uab.cat (G.P.); omargalefgeo@gmail.com (O.M.); s.pla@creaf.uab.cat (S.P.-R.); c.stefanescu@creaf.uab.cat (C.S.); loles@creaf.uab.cat (D.A.); c.preece@creaf.uab.cat (C.P.); liulei406@gmail.com (L.L.); verger@creaf.uab.cat (A.V.); a.barbeta@creaf.uab.cat (A.B.); a.achotegui@creaf.uab.cat (A.A.-C.); a.gargallo@creaf.uab.cat (A.G.-G.); g.farre@creaf.uab.cat (G.F.-A.); m.fernandez@creaf.uab.cat (M.F.-M.); d.liu@creaf.uab.cat (D.L.); c.zhang@creaf.uab.cat (C.Z.); i.urbina@creaf.uab.cat (I.U.); m.vives@creaf.uab.cat (M.V.-I.); b.stocker@creaf.uab.cat (B.D.S.); m.balzarolo@creaf.uab.cat (M.B.); r.guerrieri@creaf.uab.cat (R.G.); m.peaucelle@creaf.uab.cat (M.P.); s.maranon@creaf.uab.cat (S.M.-J.); k.bornez@creaf.uab.cat (K.B.-M.); zhaobin@creaf.uab.cat (Z.M.); a.descals@creaf.uab.cat (A.D.); jaume.terradas@uab.cat (J.T.)

2 CREAF, Center for Ecological and Forestry Applications, 08193 Cerdanyola del Vallès, Catalonia, Spain; mireia.bartrons@uvic.cat (M.B.); m.camino@creaf.uab.cat (M.C.-S.); alejandro.castellanos@unison.mx (A.C.)

3 BEECA, Departament de Biologia Evolutiva, Ecologia i Ciències Ambientals, Universitat de Barcelona (UB), 08028 Barcelona, Catalonia, Spain

4 Aquatic Ecology Group, University of Vic-Central University of Catalonia, Vic, 08500 Barcelona, Catalonia, Spain 5 Museu de Ciències Naturals de Granollers, Francesc Macià, 51, 08402 Granollers, Catalonia, Spain

6 INRA, UMR ISPA, Interactions Sol Plante Atmosphère, 33882 Villenave d'ornon CEDEX, France

7 Forestry Economics and Forest Planning, Faculty of Environment and Natural Resources, University of Freiburg, Tennenbacherstr. 4, 79106 Freiburg, Germany; dominik.sperlich@ife.uni-freiburg.de

8 Department of Scientific and Technological Research (DICTUS), Universidad de Sonora (Unison), 83000 Sonora, Mexico

* Correspondence: josep.penuelas@uab.cat; Tel.: +34-935-812-199; Fax: +34-935-814-151

Received: 21 September 2017; Accepted: 15 November 2017; Published: 24 November 2017

Abstract: The increase in aridity, mainly by decreases in precipitation but also by higher temperatures, is likely the main threat to the diversity and survival of Mediterranean forests. Changes in land use, including the abandonment of extensive crop activities, mainly in mountains and remote areas, and the increases in human settlements and demand for more resources with the resulting fragmentation of the landscape, hinder the establishment of appropriate management tools to protect Mediterranean forests and their provision of services and biodiversity. Experiments and observations indicate that if changes in climate, land use and other components of global change, such as pollution and overexploitation of resources, continue, the resilience of many forests will likely be exceeded, altering their structure and function and changing, mostly decreasing, their capacity to continue to provide their current services. A consistent assessment of the impacts of the changes, however, 
remains elusive due to the difficulty of obtaining simultaneous and complete data for all scales of the impacts in the same forests, areas and regions. We review the impacts of climate change and other components of global change and their interactions on the terrestrial forests of Mediterranean regions, with special attention to their impacts on ecosystem services. Management tools for counteracting the negative effects of global change on Mediterranean ecosystem- services are finally discussed.

Keywords: climate change; drought; global change; mediterranean forests; ecosystem services; resilience; management; migration; extinction; diversity; communities; $\mathrm{CO}_{2}$; plant invasion

\section{Introduction}

Climate change is increasing temperatures and drought in many regions around the world [1]. An increase in aridity is particularly expected in the Mediterranean regions [2,3] . If the combination of climate change, associated disturbances (e.g., floods, droughts and forest fires) and changes in other components of global change (especially changes in land use, pollution and overexploitation of resources) continues, the resilience of many ecosystems will likely be exceeded [4], altering their structure and function [5] and compromising the services they currently provide [6]. Decreases in water resources and C-storage capacity, soil erosion, soil fertility loss, desertification, reductions in the capacity of food production and endangerment of the prevalence of several species and communities are the most critical aspects to consider. Here, we review the increasingly available data for the impacts of climate change and other drivers of global change on forests at different spatial scales in the Mediterranean region and their relationships with the capacities of provision of ecosystem services. We also discuss and recommend management measures. Most of the data for the impacts of global change on organisms and ecosystems were gathered by the authors for reporting the effects of climate change on the terrestrial ecosystems of Catalonia within the "Tercer informe sobre el canvi climàtic a Catalunya" framework [7].

This study focuses mostly on new data available for the effects of climate change, land-use changes, overexploitation, pollution and species invasion and their interactions on Mediterranean forests at various levels (the genetics, epigenetics, metabolomics, morphology, physiology and phenology of living organisms, the interactions between species, species distributions and the structure and functioning of ecosystems) and their final impacts on ecosystem services. This study aims to; (i) summarize and identify the impacts of the above mentioned global change drivers on the capacity of Mediterranean forests to provide key services (water supply, C storage, food production and biodiversity conservation) and (ii) discuss and establish the most adequate recommendations to better manage the goods and services of Mediterranean forests.

To accomplish these objectives, we searched for the studies dealing with the impacts of global change on Mediterranean forests and their services in the ISI Web of Science. In our search we used combinations of the following keywords: Abandonment, activity, adaptation, agriculture, albedo, alien, animal, aridity, availability, biodiversity, carbon, climate, climate change, concentration, conservation, content, crop, cork, drought, economy, ecosystem, emission, enzyme, expansion, fertility, flowering, foliar, food, forest, global change, grass, grassland, hiking, historical, invasive, leaf, leisure, makers, Mediterranean, metabolism, morphology, mushrooms, needle, nitrogen, nitrogen deposition, nutrients, ozone, pasture, plant, phenology, phosphorus, physiology, policy, pollution, Persistent Organic Pollutants (POPs), production, recreational, regulation, root, security, society, socio-economic, soil, species invasion, shrub, shrubland, supply, storage, terpene, timber, tourism, Volatile organic compounds (VOCs), warming, and water.

The results clearly showed that drought is the main present and future concern in Mediterranean terrestrial ecosystems. The coupled effect of warming and drought increasing aridity is related with the decrease of the provision of several terrestrial ecosystem services such as soil conservation, water storing 
capacity, timber, mushrooms and food production, tourism and recreation, biodiversity and C-storage (Table 1). 
Table 1. Main recent findings grouped by climate change drivers: (i) responses from organisms; (ii) responses from ecosystems; and (iii) effects on ecosystem services.

\begin{tabular}{|c|c|c|c|}
\hline Climate Change Driver & Organismic Responses & Ecosystemic Responses & Effects on Ecosystem Services \\
\hline Warming & $\begin{array}{l}\text { Fast genetic adaptation. } \\
\text { Metabolomic shift towards activated anti-stress } \\
\text { metabolic pathways } \\
\text { Changes in elemental composition of plants } \\
\text { Morphological and metabolomic acclimation of } \\
\text { plants under moderate warming } \\
\text { Changes in phenology } \\
\text { Increase of terpene emissions } \\
\text { The increase in VOCs (volatile organic compounds) } \\
\text { will affect the signal effect of these compounds for } \\
\text { pollinators, thereby influencing their competitive } \\
\text { ability }\end{array}$ & $\begin{array}{l}\text { Desertification } \\
\text { Asymmetrical adaptation capacity among plant } \\
\text { community species drive to changes in species } \\
\text { composition at medium and long-term } \\
\text { Changes in the phenology of plant-pollinators } \\
\text { relationships } \\
\text { Increase of POPs (persistent organic pollutants) } \\
\text { concentrations in environment and organisms } \\
\text { Transformation of primary POPs to more toxic } \\
\text { secondary POPs } \\
\text { Exacerbation of phenological asynchronies between } \\
\text { plants and their pollinators. These climate-induced } \\
\text { phenological disruptions may also have unexpected } \\
\text { eco-evolutionary consequences, biasing sex ratios in } \\
\text { the populations of insect species where sex is } \\
\text { determined by temperature. } \\
\text { Shifts of species distribution areas of plants and } \\
\text { animals to higher latitudes and/or latitudes }\end{array}$ & $\begin{array}{l}\text { Decreased provision of several ecosystem services, } \\
\text { such as water storing capacity, timber, mushrooms, } \\
\text { tourism, soil conservation. } \\
\text { Less water availability for human activities } \\
\text { including food production and recreative services } \\
\text { Increased land cover not situable for farmland and } \\
\text { cropland activities }\end{array}$ \\
\hline Drought & $\begin{array}{l}\text { Fast genetic adaptation } \\
\text { Metabolomic shifts towards activated anti-stress } \\
\text { metaboloc pathways } \\
\text { Changes in elemental composition of plants } \\
\text { Morphological and metabolomic acclimation of } \\
\text { plants under moderate drought } \\
\text { Disappearance of less drought resistant species } \\
\text { under prolonged drought events and/or chronic } \\
\text { drought enhancement. } \\
\text { Changes in palatability in plant tissues } \\
\text { Changed terpene emissions }\end{array}$ & $\begin{array}{l}\text { Desertification } \\
\text { Asymmetrical adaptation capacity among plant } \\
\text { community species drives to changes in species } \\
\text { composition at medium and long-term favouring } \\
\text { drought resistent species } \\
\text { Decreases of total ecosystem nutrient content } \\
\text { Changes of allocation to nutrients from leaves to } \\
\text { roots, and from plants to soil } \\
\text { Decrease in soil mineralization } \\
\text { Increases of more recalcitrant fractions of nutrients } \\
\text { and decreases of more labile fractions in soils } \\
\text { The increasing recurrent wildfires linked to drought } \\
\text { have transformed several forested areas to } \\
\text { shrublands in the last } 20 \text { years, e.g., in southern } \\
\text { Portugal } \\
\text { Reduction of ecosystem capacity to act as C-storage }\end{array}$ & $\begin{array}{l}\text { Decreased provision of several ecosystem services, } \\
\text { such as water storing capacity, timber, mushrooms, } \\
\text { tourism, soil conservation } \\
\text { Less water availability for human activities } \\
\text { including food production and recreative services } \\
\text { Increase of land cover not situable for farmland and } \\
\text { cropland activities } \\
\text { Decrease of tourism and hiking } \\
\text { Losses of biodiversity and ecosystem C-storing } \\
\text { capacity } \\
\text { Loss of soil protection capacity }\end{array}$ \\
\hline
\end{tabular}




\section{The Changes in the Previous Millenia and Centuries}

The Mediterranean regions, like the other regions in the world, have suffered continuous changes in the distribution of forests throughout geological times. The Mediterranean basin in particular has long been densely populated, so the changes in the vegetation have been due to the combined action of climate change and human activities on the landscape for millennia.

\subsection{The Holocene}

The relatively arid conditions since the last glacial maximum (LGM, 20-19,000 years before present, $\mathrm{BP}$ ) ensured the dominance of steppe species and montane pine forests (Lake Estanya, $670 \mathrm{~m}$. a. s. 1. (meters above sea level), [8]) (Figure 1). The Pyrenean ice front, which descended to its minimum altitude around $1000 \mathrm{~m}$. a. s. 1. during the Pleniglacial [9], melted due to the gradual warming.

This regional trend was interrupted by very arid and cold episodes, such as the period known as the Younger Dryas (11,000-12,000 cal. years BP), when the xerophytic species colonized the Mediterranean area.

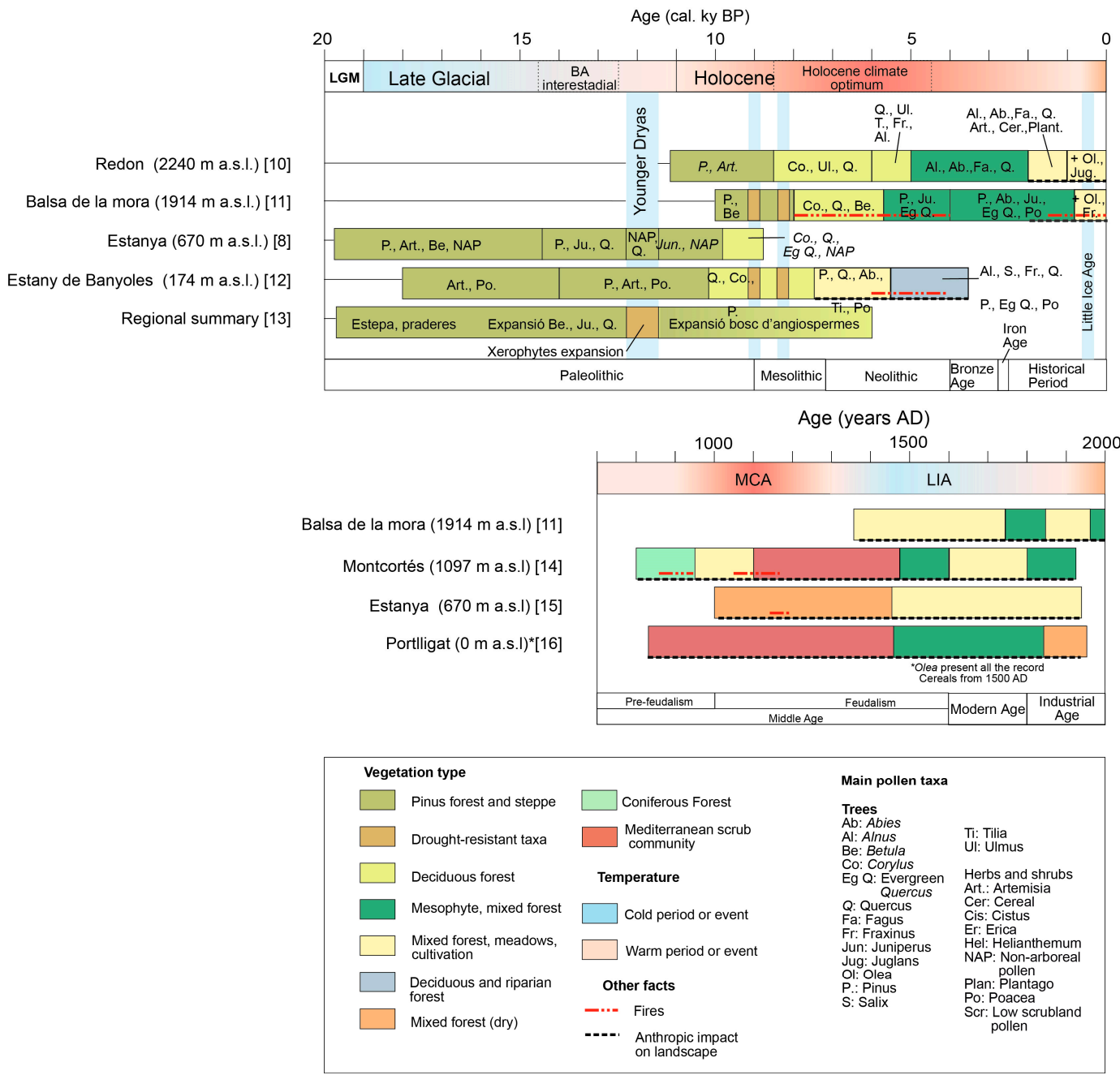

Figure 1. Main changes of vegetation in the last 20, 000 years in the northeastern Iberian Peninsula deduced from the pollen record of Lakes Redon, Balsa de la Mora, Estanya and Banyoles, with more detailed main changes in the last 2000 years deduced from the pollen record of Lakes Redon, Montcortés and Estanya and of Portlligat Bay [8,10-16]. 
Last Glacial Maximum (LGM); Cal. ky BP = Calibrated Kiloyears Before Present; Medieval Climate Anomaly (MCA), Little Ice Age (LIA), Years Before Present (BP), Anno Domini (AD), meters above sea level (m. a. s. 1.)The Holocene warming peaked during the Holocene Climatic Optimum (HCO), associated with an increasingly humid climate. The summer temperatures in the high mountains 5000-9000 years BP may have been $2-6^{\circ} \mathrm{C}$ higher than the current temperature $[10,17]$. The altitudinal limit of trees (Pinus and Betula) rose to altitudes higher than the current limit in some areas of the Pyrenees during the HCO [18]. Studies of paleosol have shown that forests grew to altitudes of 2400-2600 $\mathrm{m}$ in some regions (Plaus de Boldís-Montarenyo [18]). The start of the Holocene (11,000 years BP) in the Eurosiberian region and the Iberian Mediterranean was characterized by the expansion of communities dominated by Quercus and forests of deciduous flowering plants at the expense of pine forests and steppes. In fact, taxa such as Pinus, Juniperus and Betula and subsequently Quercus progressively spread during the beginning of the Holocene and the Tardiglacial from southern Europe toward boreal areas.

The sediments in Banyoles Lake (174 m. a. s. 1., [12]) provide a good record of the changes in landscape during the Holocene (Figure 1). The progressive warming led to the dominance of broadleaved trees in lowland deciduous forests (Quercus and Corylus), accompanied by pine forests in higher areas. Occasional periods of drought and lower temperatures in the peninsula (9300-9000 and 8200 years BP, respectively) had moderate effects on the vegetation near the lake, with slight increases in populations of Pinus, Betula and other sclerophyllous species (Olea-Phillyrea). The pollen record in high montane lakes (e.g., Lake Redon, 2240 m. a. s. 1.) from the early Holocene indicates the presence of deciduous (Corylus, Ulmus and Quercus) and Pinus (9000-6000 years BP) forests. This landscape contrasts with the predominance of Pinus forests (10-9000 years BP), meadows of Artemisia and herbs in earlier and colder periods. The Iberian Peninsula cooled around 6000 years BP, but the presence of agricultural communities near Banyoles (from 7600 to 7200 years BP) complicates the interpretation of the effects of the climate on the surrounding vegetation. The high montane areas, which were less influenced by human activities, provide a good record of the effects of climatic variability in more recent times. Hazel groves declined near Lake Redon, replaced by taxa such as Alnus, Abies, Fraxinus and Tilia. Fagus, Abies, Alnus and Pinus were the dominant species during the last 5000 years. The landscape, however, began to open around 4000 years BP (increases in Juniperus and Artemisia). Broadleaved forests have clearly declined in the last 2000 years, and vegetation associated with human occupation (Olea, Juglans and Cerealia) has increased. The interaction between the impacts of humans and climate has influenced the landscape vegetation during the last 5000 years $[17,19]$.

\subsection{The Last Millennium}

Major changes in climate during the last millennium have strongly modulated the landscape (Figure 1). The medieval climatic anomaly (900-1300 brought warmer and drier conditions to the Mediterranean region, which led to the establishment of communities of Mediterranean shrubs (e.g., Rosmarinus sp., Hedysarum sp., Heliantehmum sp. and Ephedra sp.) near Montcortès Lake $(1097 \mathrm{~m}$. a. s. 1.), which is now below $800 \mathrm{~m}$. a. s. 1. Multiple pollen records in the northeast of the peninsula (Port-Lligat, Balsa de la Mora and Estanya) indicate the presence of xerophytes and heliophytes (Quercus suber L., Juniperus and species of Cistaceae, among others), a reduction of deciduous forest species and an increase in evergreen species during the same period. The vegetation of this period, however, was strongly modified by human influence, such as deforestation and intensive pastoral activities. The shrub community around Montcortès Lake disappeared with the arrival of the little ice age (LIA, 1300-1850 AD), and the forest expanded due to the wet and cold conditions. Records at mid- and upper altitudes also indicated the expansion of deciduous forests, coinciding with an intensification of rain, with the maximum frost recorded in historical archives. The conditions have increasingly warmed since the end of the LIA, with the exception of a slight cooling at the end of the 19 th and the beginning of the 20th centuries. 


\subsection{Current Climate Change}

The numerous records allow us to reconstruct the past vegetation and help us understand the future changes of the landscape of the Mediterranean region. Mediterranean areas have also experienced an increase in aridity in the last decades. Warming trends have been registered in the Mediterranean Basin [2,20,21]. Precipitation has begun to exhibit either a long-term downward trend, mainly in the dry season [22], or no significant change [2,3,20] although in all cases a rise in potential evapotranspiration has led to increased aridity [2,3]. In South California and South Africa similar trends have been observed in the recent past and are projected for the coming decades [23,24].

The combined effect of increasing temperatures and land-use changes, such as a decrease in livestock grazing in subalpine areas in recent decades, help to explain the densification of subalpine forests or the upward shift of the altitudinal limit of the forests $[21,25,26]$. Climatic warming may also replace areas of pine forest and steppe with deciduous forests in areas with sufficient water resources. The enhancement of drought in lowlands, however, will likely promote the expansion of shrubby and xerophytic vegetation that would be better adapted to the new conditions, to the detriment of deciduous forest species. The magnitude of the transformation of the landscape, however, is difficult to quantify, because the rate of current climate change is not comparable with that of known records. In addition, the warm periods before the last few millennia were likely never as severe as those envisaged for the coming decades. Both the rate and intensity of change will determine the change to new communities better adapted to drier conditions, the incidence of fire or the migration of species between bioregions. The recent changes in land uses could overtake the impacts of climate on the landscape, e.g., the abandonment of agricultural land and reduction of intensive livestock production has promoted forest expansion.

\section{Capacity of Mediterranean Organisms and Forests to Respond and Adapt to Climate and Global Change}

\subsection{Responses at the Molecular Level and in the Use of Chemical Elements}

Genetic variability in natural populations allows adaptive and evolutionary responses to changing climatic conditions. Various techniques of molecular biology have been applied to natural forest populations. Field studies of altitudinal gradients in the Montseny Mountains [27-29] and field experiments with warming and drought manipulation in the Garraf Mountains in typical Mediterranean shrubland [30] have demonstrated that species acclimate and adapt (evolve) quickly to climate change. The frequency of alleles of genes associated with these responses to the climate have been quantified in populations, and the role of epigenetic modifications in a fast-adaptive response has been determined. As an example of the latter, a field experiment with climatic manipulation found that Quercus ilex L. responded quickly to experimentally induced drought by epigenetic changes such as DNA methylation [31].

Decreases in the activities of metabolic pathways associated with growth and the accumulation of energy and increases in the secondary metabolic pathways associated with anti-stress mechanisms in response to drought have been identified in dominant species of Mediterranean shrubs and trees by metabolomic analyses [32-34]. These changes in metabolomic profiles were associated with changes in the elemental composition and stoichiometry of the organisms [32,35]. Changes in the chemical composition of plants under drought and/or warming affect the palatability of plants and therefore the frequency of herbivorous attack $[33,36,37]$. Aerial organs and roots of the same plant can also respond oppositely to drought and warming [36,37]. The concentration of primary metabolites associated with protein synthesis and energy production, such as amino acids and sugars, and N, P and $\mathrm{K}$ concentrations increased in roots, whereas activities of the primary metabolic pathways associated with growth and N, P and K concentrations decreased in the aerial organs. These differences between foliar and root responses add further complexity to the consequences of climate change on ecosystems, 
e.g., at the level of trophic webs, with possible asymmetrical effects on above- versus belowground trophic webs.

Responses of $\mathrm{C} / \mathrm{N} / \mathrm{P} / \mathrm{K}$ ratios to environmental changes constitute a first step towards an altered flow of matter and nutrients through the trophic chain and, therefore, a modification of the biogeochemical cycles of the plant-soil system [38,39]. Studies of climatic gradients have found that the foliar $\mathrm{C} / \mathrm{N} / \mathrm{P} / \mathrm{K}$ stoichiometric ratios of the main forest species were mostly dependent on the meteorological conditions, especially rainfall in Catalan forests $[40,41]$. We have also observed changes in $\mathrm{C} / \mathrm{N} / \mathrm{P} / \mathrm{K}$ stoichiometry and the concentrations of macro- and micronutrients in plants and soil in our field climatic-manipulation experiments [42,43]. Water availability was not only associated with shifts in nutrient concentrations but also with their allocation to different organs [41,44], the stoichiometric relationships among the main nutrients $[41,44,45]$ and the distribution of nutrients between plant and soil [43,45-47]. Drought tends to decrease total nutrient contents in plant-soil systems, mainly in plants, that transfer nutrients from above- to belowground biomass and from plant to soil $[44,48]$. This modification of the biogeochemical cycles of the plant-soil system in response to environmental changes constitute a first step towards an altered flow of matter and nutrients through the trophic chain [38]. The impact on the structure and diversity of plant communities of this variable distribution of nutrients in the plant-soil system together with the high resource allocation to roots under drought could have different effects in different Mediterranean regions. Australia and South Africa have lower availabilities of natural soil nutrients than the Mediterranean Basin, California and Chilean regions [49], which could imply different capacities to adapt to this new situation in both groups of regions, thus constituting a promising research line.

The impacts of climate change on plant-soil nutrient cycles overlap the changes in elemental composition in plants due to anthropogenic pollution [40,50]. Recent studies of Pinus uncinata Ramond ex A.DC. across altitudinal gradients in the Pyrenees have shown that mortality associated, at least partially, with damage from ozone pollution was high in populations at high altitude [51,52]. The impacts of pollution associated with large metropolitan areas are also common in all Mediterranean areas, with consequent impacts in wider surrounding areas. For example, changes in foliar $\mathrm{N}$ and sulfur (S) concentrations in some dominant tree species in northeastern Iberian Peninsula significantly depended on gradients of $\mathrm{N}$ and $\mathrm{S}$ deposition, mainly as a function of the distance from the Barcelona metropolitan area [40]. How pollution, particularly from $\mathrm{N}$ deposition, $\mathrm{O}_{3}$ formation and new pollutants (such as medicines), can interact with climate change to affect Mediterranean ecosystems is poorly understood [53].

\subsection{Changes in Morphology, Physiology, Phenology and Growth in Plants}

A climatic-manipulation field study in a Mediterranean holm oak forest found a small reduction in growth and an increase in defoliation, both leading to a decrease in biomass accumulation [54-56]. Extreme droughts in the last two decades have also increased mortality rates [57]. These negative effects, however, have progressively decreased, probably due to epigenetic adaptation and/or a decrease in foliar biomass and/or number of individuals [55]. Moreover, the effect of drought can increase over time by the exhaustion of soil deep water [58]. Some Mediterranean plants can quickly respond to increasing drought to enhance their water-use efficiency, but this response is accompanied by a decrease in growth capacity [59].

Photosynthesis and morphological attributes in several tree species have acclimated strongly to variations in seasonal climatic conditions $[60,61]$. We have also observed strong seasonal acclimation to the thermal optimum and the response of photosynthetic assimilation to the temperature $[54,61]$. Photosynthetic mechanisms are resilient to moderate droughts, but severe droughts induce the acclimation of morphological attributes and a decrease in photosynthesis [61]. An insufficient recovery of groundwater early during the growing season severely exacerbates the effects of summer droughts [61]. The acclimation of each species thus partially compensates for these general trends in response to drought stress and temperature $[54,58,61]$. 
The success of evergreen species in the future dynamics of competition and environmental conditions will depend on both their resistance to abiotic stress and on their ability to benefit quickly from periods of favorable environmental conditions [62]. Phenological changes are, and will continue to be, among the most widespread consequences of climate change [63-65]. An increase in maximum temperatures is more crucial than an increase in mean temperatures [65]. Climate change, in addition to affecting the emergence of leaves and the time of flowering, also affects the phenology of leaf fall in winter in deciduous species, although warming and drought have opposite effects [66]. Warming generally delays leaf senescence, and drought has the opposite effect, but with variable intensity depending on the species [66]. The impact of climate change will therefore depend on the relative importance of each factor in specific regions or years. The resorption of nutrients before leaf senescence is reduced when the leaves fall prematurely due to stress. The effect of climate change on nutrient resorption is therefore a balance between the conflicting effects of drought and warming [66]. This aspect is important, because the production of new foliage is based almost exclusively on nutrients reabsorbed into the foliage during the previous autumn.

The emission and accumulation of terpenes from and in plants are also altered by warming and aridity [67,68], with multiple effects on the ecosystem and even the local climate [69], biotic relationships such as potential variations in the palatability of plant tissues and deterrence of herbivores [70] or the signals to predators [71] and pollinators [72-75]. Terpene content has decreased significantly in plant tissues of forest trees subjected to experimental drought, but total emissions have increased, especially in spring and autumn $[67,76]$, with large differences among species $[67,77]$. These results have led to a better understanding of the interannual and seasonal behavior of volatile plant compounds in Mediterranean conditions, a matter of great interest because of the importance of these compounds to the flammability of the forests and to atmospheric chemistry [78,79]. The effects of climate change on terpene emission also contribute to atmospheric pollution [80,81], which can be important in large urban areas $[80,81] \mathrm{N}$ loads from atmospheric deposition may also alter plant terpene emission, as observed experimentally [82].

\subsection{Changes in Morphology, Physiology, Phenology and Growth in Animals}

Animal species, like all forms of life, face the challenges of climate change by three main strategies: (1) shifting phenologies (and behaviors), (2) changing morphological, physiological or life-history traits and (3) adjusting their distributional ranges [83]. The first two strategies necessarily involve processes driving adaptive changes via microevolution (i.e., mutation and selection of existing genotypes) or plasticity (i.e., the capacity of a genotype to produce phenotypic alternatives under varying environments, [84]). Phenotypic plasticity has long been recognized as having a high adaptive value $[85,86]$. Recent studies with an insect model species, Pieris napi L., a butterfly whose genome has been sequenced, have described annual cycles of phenotypic traits associated with temperature (Figure 2). In particular, annual cycles in characters such as the darkening of the wings have been observed, with significant differences between high-altitude and lowland populations (Figure 2A,B). Breeding experiments under laboratory conditions have shown that temperature induces significant changes in the darkening of individuals, supporting the observations in natural populations. This evidence suggests that the higher temperatures predicted for the future may alter the phenotypically characteristic annual cycles of both high-altitude and lowland populations. 
A
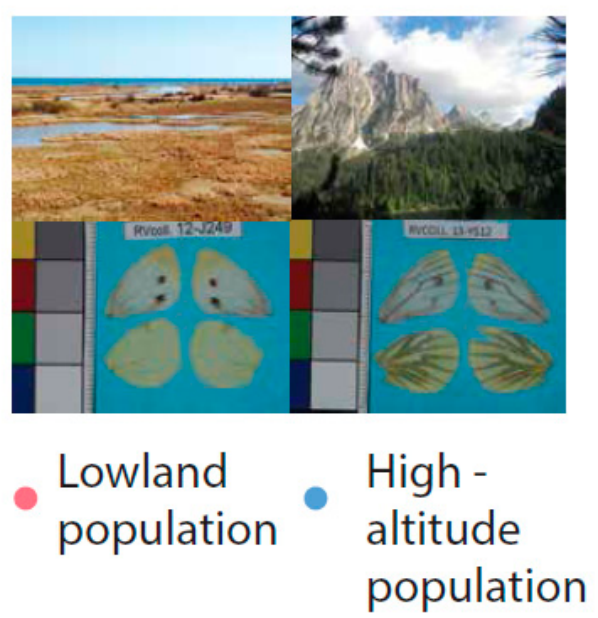

B

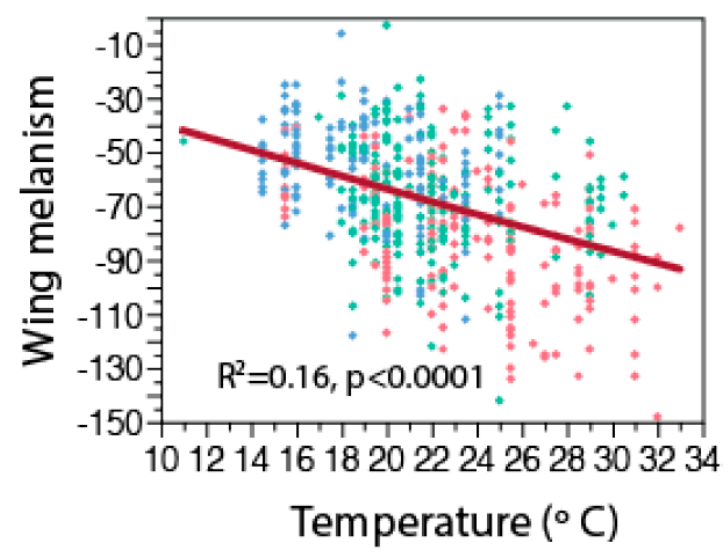

C

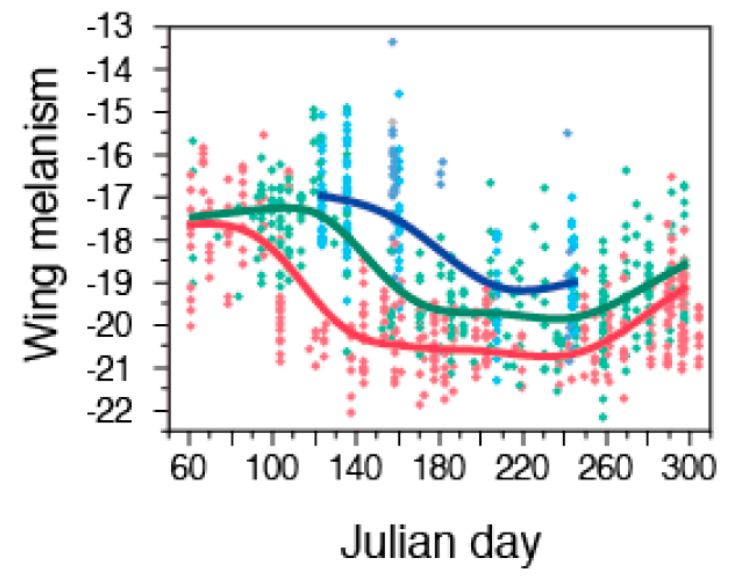

Figure 2. (A) Variation in the phenotype of Pieris napi wings between a high-altitude location (2000 m) and a coastal wetland location; (B) Relationships between observed darkness of the wings (melanism) and the temperature of the location where they were found; (C) Annual variation of wing darkness (melanism), a key functional attribute associated with thermoregulation and drought-induced responses. The trends for three populations of $P$. napi sequentially arranged along an altitudinal gradient in the Pyrenees are shown (red, low wetlands; green, mid-altitude site (535 m); blue, high-altitude site $(2000 \mathrm{~m})$ ). Melanism was measured in standardized units relative to reference color-card standards.

Plasticity has also been hypothesized to be important for shifts in the periods of activity and phenologies of several groups of animals in response to climate change $[87,88]$. Notable changes in 
the arrival dates of migratory birds [89] and advances in the first appearances of several pollinators, which could be tracking the parallel shift in the flowering times of their host-plants [90], have been reported for the Mediterranean Basin. The increase in aridity, however, may also exacerbate phenological asynchronies between plants and their pollinators, as has been recently suggested for several Mediterranean butterflies [91]. These climate-induced phenological disruptions may also have unexpected eco-evolutionary consequences, biasing sex ratios in the populations of insect species where sex is determined by time and temperature [92].

Evidence is accumulating of displacements in the distribution of populations of species toward the poles and higher altitudes following their climatic niches [93]. Determining if these changes in distribution will be fast enough to cope with current climate change, or conversely if species and communities are acquiring climatic debts, is therefore crucial [94]. Ample evidence suggests that these distributional changes are ultimately influenced by microclimatic effects, behavioral buffering and genetic and epigenetic adaptations [95-99]. Biotic interactions can also strongly modify the species-specific capacity to disperse and thus should also be included for developing more robust models for predicting future species distributions [100].

We are beginning to understand the main responses of animal species to climate change, but we still need to deepen our understanding of the eco-evolutionary mechanisms behind the responses [101]. We must also anticipate which species are under the greatest threat (e.g., relict species, species near their physiological limits or species with low dispersal capacity, low plasticity or low adaptive capacity, [98,102]. Furthermore, this information is vital for guiding effective management and conservation policies that are urgently needed to reduce the current rate of loss of animal diversity [103].

\subsection{Changes in Populations and Communities}

Different species can respond differently to climate change, thus generating both demographic changes and changes in the composition and functioning of communities, such as observed in invertebrate populations $[102,104]$, many of them with a high impact on forest processes such as litter decomposition. However, tree species are also not equally affected by drought conditions. For example, productivity has decreased and rates of mortality and defoliation have increased significantly in the holm oak, a species currently dominating Mediterranean forests, but tall shrubs have adapted better to arid environments, with minimal effects from the same droughts [55]. If the Mediterranean climate becomes drier, as forecasted for the coming decades, holm oaks could be partially replaced by these tall shrubs, thereby decreasing the capacity of the region to sequester atmospheric $\mathrm{CO}_{2}$. Opposite demographic responses have recently been identified in gymnosperms and angiosperms of the Mediterranean region [102,105]. Quercus species are currently widely succeeding gymnosperms in the Iberian Peninsula. The differences in the basic attributes of these two groups of plants account for their different responses to temperature and their different roles during succession [102,105]. Consistent with this result, climatic-manipulation field experiments have found that drought affected some species more negatively than others, providing evidence of a demographic change by favoring the most drought-resistant species [58,106,107].

\subsubsection{Impacts of Altered Emissions of Fragrances by Leaves and Flowers on Communities}

Plants emit a large quantity and variety of volatile organic compounds (VOCs) [108], such as the terpenes mentioned above, with multiple physiological and ecological functions that, in a cascade effect, can affect communities of organisms, ecosystems, atmospheric chemistry and even meteorological conditions [68,69]. Projections predict a substantial increase in these emissions in response to most of the global change drivers [68,109]. Among these, temperature has a greater effect on volatile organic compounds (VOC) emissions, because it increases the volatility of these compounds and stimulates their synthesis [67,110-112]. In fact, emissions increase in response to increases in temperature from vegetative tissues such as leaves, which release the largest fraction of VOCs emitted by vegetation, and from other structures, such as flowers, that play very important biological roles $[72,73,75,113]$. 
Emissions of VOCs from flowers will increase with temperature, although the magnitude of the change will depend on the species [74]. The increase in VOCs will increase the signal effect of these compounds for pollinators, thereby influencing their competitive ability [74]. An increase in temperature is also expected to cause changes in the relative composition of floral scents, which could therefore disrupt the effectiveness of floral location by pollinators, because the scents are signals for specialist pollinators $[74,75,114,115]$. Another recent study has shown that the fragrance of a flower depends on the composition of the fungi and bacteria living on its surface, which in turn is strongly influenced by water availability and temperature [116]. Other phenomena associated with global change can also affect VOC emissions. Exposure to high concentrations of ozone can stress plants, which will increase their emissions of VOCs $[117,118]$ but will also considerably shorten the longevity of the emitted VOCs by their rapid oxidation, interfering with some of their ecological functions [119]. Ozone reduces the concentration of VOCs in floral emissions with distance and modifies the relative composition, reducing the effective distance for attracting pollinators to flowers [119].

\subsubsection{The Effects of Pollutants on the Interaction with Climate Change: The Example of Persistent} Organic Pollutants

Persistent organic pollutants (POPs) are synthetic, toxic substances associated with agricultural, urban and industrial activities. They are distributed around the planet. The available data for Mediterranean regions indicate that concentrations of these compounds in the human population were similar to those in the United States and Germany, the only countries that have regular follow-ups [120]. The strong agricultural and industrial pressure in the Mediterranean Basin, especially from the textile and plastic industries, may be the cause of these high POP concentrations in the Catalan human population [121]. The production and use of most POPs are forbidden, but these pollutants remain in the environment at relevant concentrations, especially in the temperate zones of the Northern Hemisphere [122].

The physical and chemical properties of POPs determine their volatility and condensation, and temperature is a key factor determining the transport of these pollutants at global, regional and local scales (Figure 3). Changes in temperature, such as those that have occurred and those that are expected due to climate change, can therefore influence the distribution and redistribution of these compounds. The scientific literature on this subject is unfortunately scarce and lacks a precise quantification of the effects of climate change on the dynamics of these pollutants, but early data have indicated the re-volatilization of POPs in cold areas induced by the effects of climate change [123].
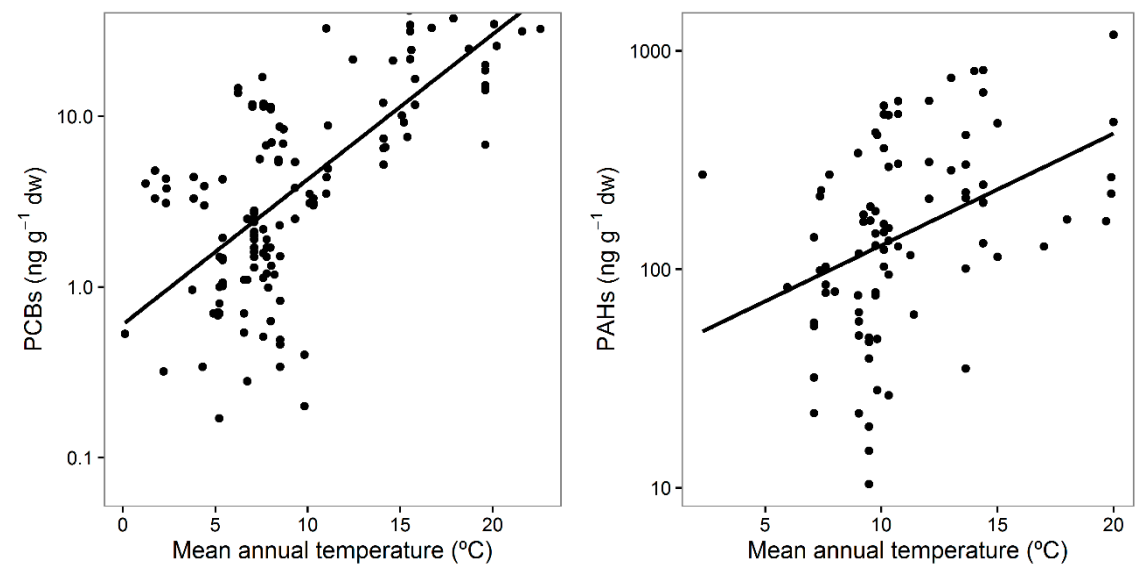

Figure 3. Relationships between the mean annual temperature (MAT) and the foliar concentrations of PCBs (polychlorinated biphenyls) and PAHs (polycyclic aromatic hydrocarbons) in gymnosperms (generally Pinus sylvestris L.), probably influenced by the increased emission and re-emission of pollutants in warmer areas. PCBs $=0.08 \mathrm{MAT}-0.22, R^{2}=0.45, p<0.0001$; PAHs $=0.05 \mathrm{MAT}+1.60$, $R^{2}=0.16, p<0.0001$. 
The temperature increases in the Mediterranean region are directly affecting the partition equilibrium phase of these semi-volatile substances, promoting their revolatilization to the atmosphere [124]. The increase in the concentrations of POPs in the atmosphere accelerates their mobility and dispersal [125], which promotes the transfer and condensation of these pollutants in colder areas. In fact, up to an estimated 22\% of the PCBs in Mediterranean regions will have migrated to northern Europe and the Arctic Ocean by 2100. The increase in temperatures is also expected to accelerate the biotransformation of POPs to new, structurally similar but often much more toxic and persistent congeners, as has been observed in microbial mats in lakes in the Pyrenees [126]. Changes in the biodiversity and trophic structure of ecosystems are other consequences of climate change that may have direct effects on the transfer, distribution and bioaccumulation of POPs in food webs [127]. The possible and severe effects of increases in temperature on the toxicity of these anthropogenic pollutants in ecosystems should thus be considered.

The decrease in precipitation in the Mediterranean region could lead to a reduction of the wet deposition of POPs, which is a key input of the less hydrophobic POPs (e.g., HCH, HCB, PCB, DDT and DDE) to montane ecosystems [124]. The increase in the probability of torrential storms and floods in the Mediterranean region, though, could increase the release and remobilization of the stocks stored in soils and sediments, which has already been observed in other regions such as Bohemia [128]. Finally, changes in the patterns and speeds of the winds associated with climate change may also accelerate the atmospheric transport of POPs over long distances in gaseous phases or associated with particles.

\subsection{Biogeochemical and Ecosystem Responses}

An increase in the intensity, frequency or duration of drought can negatively affect Mediterranean forests [129]. A long-term (14 year) field experiment simulating drought in a $Q$. ilex forest, however, identified a dampening effect of drought over time. The differences in growth and mortality between the control and droughted plots decreased or disappeared in the first years of the experiment $[54,55]$. The overall ecosystem in the droughted plots had adapted to the lower water availability, partially by the reduction of competition among individual plants due to a decrease in basal area in the droughted plots from a higher mortality than in the control plots. Adjustments to the morphology, allometry and physiology of the trees by epigenetic modifications may have also contributed to the acclimation of the forest to the drier environmental conditions [130]. The use of stable isotopes has shown that droughted trees took up water from deeper sources in wet seasons [58]. This difference could be due to the differences in fine-root distribution between the control and droughted plots. The fine roots of droughted trees may reach greater depths to avoid summer desiccation. The experimentally induced drought instead decreased the use of deeper water sources during summer, probably due to the depletion of water trapped in fractured rock [58]. All these studies have demonstrated that the capacity of holm oak forests to adapt to increased drought is even more important than initially thought. This capacity, however, may not be sufficient to mitigate the effects of extreme episodes of drought and warming [131]. Experiments that investigate the consequences of extreme climatic events in Mediterranean ecosystems, particularly Mediterranean forests, are clearly warranted.

Analyses of the data from the Catalan Forest Inventory have shown that nutrient contents and allocation to different organs (leaves and wood) are significantly correlated with the weather, especially with mean annual precipitation [40,41], demonstrating the importance of water availability in Mediterranean forests and the disproportionally large impacts on the ability of forests to retain and accumulate nutrients that small changes in water availability can produce. Field studies simulating climate change have found decreases in the contents and concentrations of macro- and micronutrients in a Mediterranean forest [42,43,46], except for $\mathrm{K}$, which can increase in the aerial organs of some species [42]. Our field experiments have also shown that drought can increase foliar $\mathrm{C}: \mathrm{N}$ and C:P concentration ratios, which is associated with morphological strategies for adapting to drought such as sclerophylly [132]. Drought also induced changes in the allocation of $\mathrm{N}$ to roots, probably to help meet the increased need for water [133]. Field experiments simulating climate 
change have demonstrated that drought has large impacts on soil traits, particularly $\mathrm{C}$ and nutrient status $[48,134,135]$. These experiments have found that soil respiration and the activities of soil and rhizospheric enzymes have been strongly and negatively affected by drought $[48,134,135]$. A decrease in soil enzymatic activity was directly correlated with soil water content [48]. The capacity of the plants to accumulate nutrients decreased under drought, which together with a decrease in soil mineralization would increase the accumulation of nutrients in the soil, and a scenario of torrential rain would increase nutrient losses by leaching $[5,136]$. All these results provide important clues as to which species could be most damaged by increased drought in Mediterranean forests, allowing us to predict the mediumand long-term changes in the structure of plant communities if climatic projections are correct.

The presence and spread of alien species, an emerging phenomenon in several areas of the Mediterranean Basin [137], are partially replacing native species and are having a large impact on ecosystemic function, particularly nutrient cycles [137-139], and frequently decrease the rates litter decomposition [140]. Invasive plant species in Mediterranean regions frequently negatively affect the cover of understory vegetation [141] and/or change species compositions [142,143], usually reducing species diversity [142,144]. A literature review by Erskine-Ogden et al. [145] found that Mediterranean invasive woody species could increase their competitive advantage over native species under $\mathrm{N}$ deposition by their larger mass and leaf area and their early height advantage. The higher capacity of these invasive species to increase root growth under drought can also confer a competitive advantage. The success of plant invasion is an emerging problem affecting all continents, but particularly the Mediterranean Basin and its islands [139], with general impacts on plant-soil nutrient status [146].

Forests Versus Shrublands and Grasslands

Pine species (more drought resistant) were widely replaced by broadleaf species, mainly of the Fagaceae family, in Spanish forests between 1990 and 2002 [105,147], mainly due to past land uses, fire history, abandonment of forest management and abandonment of remote areas by humans and much less due to climate change. This drive to a new land cover with fewer drought-resistant species decreases the resistance and resilience of global forests against drought. New forests in Spain, though, represent $22 \%$ of the current forest cover, defining new forests as those growing on cropland abandoned since 1956 [148]. These new forests are mostly rapidly growing young trees that have been able to store 9\% of the total C emitted in Spain between 1986 and 2007 [148]. A parallel history has been observed in the Corsica Mountains, where forest cover has spread and where natural native forests of $Q$. ilex and P. pinaster Aiton have expanded against Castanea sativa Miller forests, which were previously maintained by human management but are now abandoned [149].

The increasing drought but mainly recurrent wildfires have transformed several forested areas in southern Portugal to shrublands in the last 20 years [150]. In fact, the increased forest cover on abandoned land in Mediterranean mountainous areas during the last century is now under high risk of degradation and fire due to the increasingly arid conditions [151]. This uncertainty in future projections for Mediterranean forest cover and species composition as a result of the strong interaction between land use changes and increasing drought is exacerbated by the effect of $\mathrm{CO}_{2}$ fertilization that some models assume can counteract the negative effects of drought, at least for some species [152]. A review by Doblas-Miranda et al. [153] recently concluded that global change research in Mediterranean forests should give more attention to forest decline due to drought and the relevance and interactions with historical land use.

The increase in the risk of fire due to the accumulation of highly flammable litter from exotic species as a consequence of $\mathrm{N}$ deposition is an example of the potential sinergistic impacts from drought, species invasions and $\mathrm{N}$ deposition [154]. This increased risk is a serious concern in arid shrublands and grasslands in southern California with a Mediterranean climate, where the probability of fire increases exponentially above a threshold of $\mathrm{N}$ loading [154]. The combined effects of drought and $\mathrm{N}$ deposition increases the pools of soil labile $\mathrm{N}$, suggesting a build-up of available $\mathrm{N}$, with unpredictable effects on soil trophic webs, plant-community diversity and C-storage capacity [155]. The potential 
increase in litterfall production together with the increasing frequency of fire in the Mediterranean area of southern California can favor the spread of shrubs able to sprout over shrubs that depend on seed germination [156]. Sprouting species in the shrublands of the Mediterranean Basin have a larger capacity than seed plants to regenerate after fires, even in drought conditions [157].

Moreover, the capacity of survival of Mediterranean shrubs under drought has been associated with their ability to use belowground resources, particularly water and $\mathrm{N}$ [158], indicating that drought can decrease the number of species under long-term increases in drought by the suppression of species with a low root: stem ratio and/or a low plasticity in the modification of this ratio. This capacity to survive is associated with the large capacity of Mediterranean shrublands to retain $\mathrm{N}$ in the ecosystem, as in post-fire Mediterranean shrubland communities that can recycle most of the $\mathrm{N}$ released during a fire, even with the absence of N-fixing species [159]. Other studies also suggest probable changes in species composition associated with prolonged drought conditions in various Mediterranean shrublands, given the different intensities of effects of drought among community species at the levels of growth, photosynthetic capacity and reproduction [107,160-167]. The loss of shrubland cover may be the key step toward desertification. Some studies have observed a series of positive feedbacks in the mode of desertification when Mediterranean shrublands are submitted to drought [168,169]. The first effect of drought was a reduction of growth and reproductive success [170] and thus a decrease in plant cover and litter quality. This effect was followed by decreases in soil moisture, respiration and rates of nutrient cycling that in turn impeded further plant production, growth capacity and water-use efficiency [168,169]. Finally, an increase in the intensity and/or frequency of fire in drier environments is another indirect way that drought can transform the Mediterranean landscape. The fires of the last millennia in several regions of the Mediterranean Basin were responsible for the current establishment of fire-adapted communities such as macchia [171], strongly suggesting that triggering fire recurrence can produce irrecoverable losses in biodiversity. Similarly, long-term reductions in water availability or warming significantly decrease shrubland diversity, as observed in a long-term (20 year) field experiment of climatic manipulation at the community level in the Garraf Mountains (northeastern Spain) [172].

The history of Mediterranean grasslands differs greatly from the current situation in various areas of the world [173]. Grassland covers about 35\% of the total surface in the northern Mediterranean area [173]. Most of these Mediterranean grasslands have supported extensive grazing for centuries. Mediterranean grasslands, however, may be more resistant to increasing drought severity and frequency than predicted [174]. Scenarios of increasing drought suggest that Mediterranean grasslands could lose species diversity by affecting particular species [175]. Grazing management should be reconsidered to provide appropriate levels of grazing pressure, because the impacts of grazing on grassland biomass and diversity can be very detrimental and can endanger the capacity of grassland services, and should be reconsidered to allow further grazing, especially in a scenario of increased aridity [176,177]. Important grassland types, such as semi-natural calcareous grasslands, have evolved with the history of human activity, which has generated and maintained these habitats by extensive grazing and mowing. Global change is already affecting all Mediterranean grassland types, by drought, land abandonment and $\mathrm{N}$ enrichment, as observed in central Italy [178]. Other effects linked to warming in Mediterranean areas have also been described. Jiménez-Alfaro et al. [179] observed a reduction in grassland diversity associated mainly with losses of dry grassland specialist species under warming conditions in the Guadarrama Mountains in central Spain. The encroachment of grasslands by woody plants (trees and shrubs) in some areas of the northern Mediterranean Basin is also increasing. The most realistic scenarios suggest that more than one-third of the current grassland in some areas of southern Italy would be lost to encroachment in the next 150 years [180].

\subsection{Impact of Climate Change on Mediterranean Forests Projected for the Coming Decades}

The GOTILWA+ model of forest growth [181-184] has used the Spanish Forest Inventory database to evaluate the response to climate change of different forest types under different scenarios of future 
climate. Projections for the scenarios of climate change were obtained from the general circulation model ECHAM4 (fourth generation Max-Planck-Institute model) and the A2 socioeconomic scenario from IPCC (International Panel on Climate change), which project $850 \mathrm{ppm}$ of atmospheric $\mathrm{CO}_{2}$ by 2100. GOTILWA+ outputs indicated a progressive increase in gross primary production in the northern and northeastern forests of the Iberian Peninsula, interpreted by a progressive increase in atmospheric $\mathrm{CO}_{2}$. Net primary production, however, is projected to decrease due to higher autotrophic respiration, implying a decrease in forest biomass in the forests of the Iberian Peninsula [185]. An increase in evapotranspiration and decreases in the growth of Spanish forests and the fraction of the precipitation available downstream for water systems are also expected.

\subsubsection{Shifts in Forest Cover and Carbon Uptake}

Time series of satellite data are particularly useful for studying the impacts of climate change on terrestrial ecosystems and in particular the shift in forest cover. Key parameters for the importance of the impacts on surface processes such as photosynthesis, respiration or transpiration can be estimated based on the parameters obtained by remote sensing, such as the leaf area index (LAI) or the fraction of absorbed photosynthetically active radiation (fAPAR). The Advanced Very High Resolution Radiometer AVHRR sensor on National Oceanic and Atmospheric Administration of U.S.A.-NOAA platforms has obtained global time series since $1981[186,187]$ with forecasts of future continuity by international programs of meteorological organizations (NOAA, European Organization for the Exploitation of Meteorological Satellites-Eumetsat). Changes in the dynamics of the vegetation in the Mediterranean region during the last 30 years indicate an increase in the amount of vegetation (Figure 4). The LAI trends can be explained by the increases in temperature and $\mathrm{CO}_{2}$ level, and the availability of water was mainly associated with LAI annual variability.

Diagnosing and understanding the spatial and temporal variations in photosynthetic capacity and quantifying the response of photosynthesis to climate change is also of great importance for quantifying the absorption of $\mathrm{C}$ by photosynthesis, and remote sensing is one of the most appropriate tools. The use of the photochemical reflectance index (PRI) to estimate photosynthetic performance has increased in recent years and has become a promising indicator of the response of photosynthetic rate to climate change [188-191].

In the mesic areas, forest abandonment has resulted in greening, increased green biomass (Figure 4), but in the most arid areas, the most extreme shift in forest cover is desertification. Desertification is linked to a continual positive feedback of a higher frequency of intense droughts coupled with intense torrential rains (associated with climatic change) and thus anincrease in soil erosion is the greatest threat to Mediterranean soils, especially in the most xeric areas, which in turn could lead to a loss of soil fertility and thus plant cover. These effects are strongly connected to human activities (such as excessive livestock pressure), changes in land uses and the increasing frequency and extent of fires, especially in the European Mediterranean region [192]. The abandonment of human settlements due to the abandonment of extensive farming in rural areas is also favoring desertification in several parts of the Mediterranean Basin [193]. African land in the southern Mediterranean Basin is drier than land in the northern part of the Basin. Desertification in the north is driven by intensive irrigation and by past and current over-exploitation of the vegetation, e.g., by livestock pressure, all driven by markets and regional agricultural policies, whereas desertification in Africa is driven more by the increased encroachment of rangeland by cultivation or livestock production in recent decades due to the exponential growth in population [193]. Moreover, community succession and soil processes after fires and/or increasing droughts in Mediterranean plant communities have created patchy vegetation and accelerated soil degradation [194], reducing water infiltration [195], all of which lead to desertification. Several Mediterranean areas of European countries have been subjected to land-use change in recent decades [196-198], whereby unproductive areas were forested, abandoned or overexploited [198]. Excessive grazing pressure is still generating and modulating the 
patchy distribution of vegetation in several semi-arid areas of Spain, Greece and Morocco, which is increasing desertification [199].

These processes may favor a general trend towards shifts in forest covers to semi-arid shrublands, and in the worst cases, towards more advanced steps of desertification [197], coinciding with the general increase in aridity [196,200-202]. This cascade of positive feedbacks between more aridity and the abandonment of traditional oil uses, over-exploitation, encroachment, soil erosion and degradation has been observed in some studies in southern Spain [203-206] and is especially favored and accelerated by the increase in aridity [206]. The loss of plant biodiversity during desertification also decreases the resistance of the plant-soil system to drought [207], further favoring the advance of soil erosion and desertification. Slopes and highly erodible bedrock accelerate this process [205], favored by the high frequency of torrential rain [208]. Moreover, the photodegradation of litter increases when plant cover decreases [209], thus increasing the loss of soil organic matter and contributing to soil degradation. Soil erosion is becoming the primary environmental concern in human economic balances in Mediterranean regions [210], aggravating the effects of the decrease in water resources in a negative synergistic effect and thereby reducing the provision of nearly all ecosystemic services, including food resources production capacity.

A

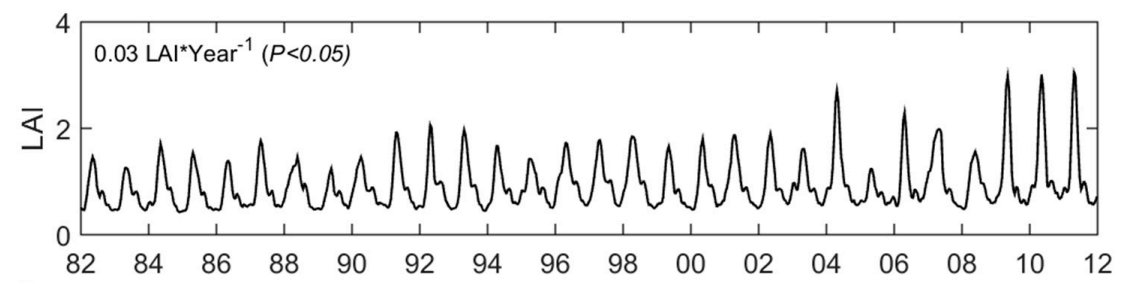

B

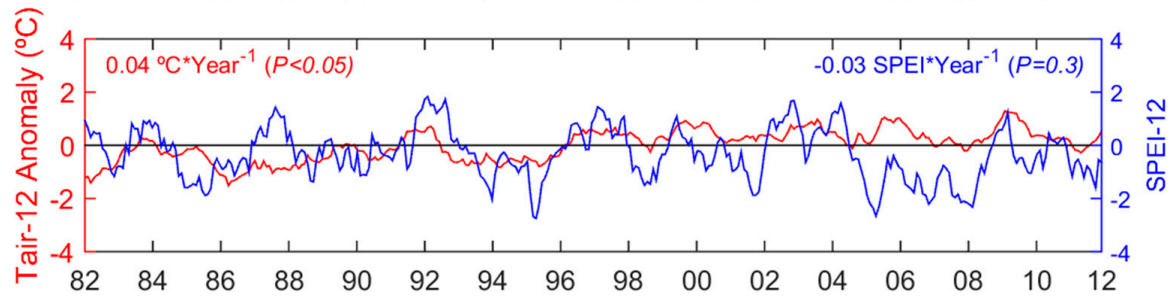

Figure 4. (A) Temporal profile of the leaf area index (LAI) GIMMS3g [186] at a spatial resolution of $0.5^{\circ}$ centered on $41.25^{\circ} \mathrm{N}$ and $1.75^{\circ} \mathrm{E}$ in the Prades Mountains (Catalonia) for 1982-2012. A trend of $0.03 \mathrm{LAI}^{*} \mathrm{Year}^{-1}$ was significant and positive. (B) Anomalies in the annual air temperature (Tair-12) [211] and the SPEI drought index accumulated yearly (SPEI-12) [212]. The trend in the temperature change of $0.04{ }^{\circ} \mathrm{C}^{*} \mathrm{Year}^{-1}$ was significant and positive, but the negative trend for SPEI was not significant. The mean annual temperature in this area is $13.5^{\circ} \mathrm{C}$ and the mean annual precipitation is $528 \mathrm{~mm}$.

\subsubsection{Biological Feedbacks on Climate Change}

Organisms and forests are not merely passive objects of climate change. The subsequent changes in their structures and activities in turn have important effects, both biophysical and biogeochemical, that reinforce the changes in climate.

Biogeochemical processes include $\mathrm{C}$ fixation, specifically the function of ecosystems as sinks of atmospheric $\mathrm{CO}_{2}$, and the emission of VOCs. Many complex processes subject to many interactions are involved in the $\mathrm{C}$ balance of Mediterranean forests. Maintaining this balance is not an easy task, despite recent progress, especially when diverse temporal and spatial scales are involved. The uncertainties caused by all the environmental conditions that interact with these processes are not entirely known. For example, how the increase in atmospheric $\mathrm{CO}_{2}$ will translate into higher $\mathrm{C}$ fixation by plants is not clear, because other factors such as drought or nutritional imbalance determine, in some cases, the decreases in the capacity to fix C. Similarly, biogenic volatile organic compounds (BVOCs), 
which are organic compounds capable of generating aerosols and cloud condensation nuclei but also capable of causing a greenhouse effect by lengthening the lifetime of $\mathrm{CH} 4$ because they consume hydroxyl radicals and alter the heat of condensation, affect the climate in a manner and intensity still to be elucidated, but potentially significantly $[44,69]$.

The biophysical effects of the changes in the activity and structure of vegetation produced by climate change are particularly important and are associated with latent heat and albedo (Figure 5). For example, the same phenological changes in the presence of leaves mentioned in previous sections may have increased $\mathrm{CO}_{2}$ sequestration but also the consumption of soil water. Forests can transpire heavily and accumulate a lot of wood under wet conditions, which may encourage cloud formation that refreshes the atmosphere and increases rainfall. Trees in the Mediterranean region receive a lot of radiation during periods of summer drought but do not have enough water to generate this effect, which further warms the climate of these areas. This phenomenon may have played an important role in recent heat waves, such as that of 2003 [213]. The decrease in groundwater also affects the overall functioning of vegetation and therefore of the ecosystem. The extension of the period of activity of deciduous trees with climate change may have conflicting effects; we may expect mitigation and/or amplification of this phenomenon, and the balance will depend on the availability of water and on regional specificities, highlighting the need to pursue this line of research with more quantitative studies.
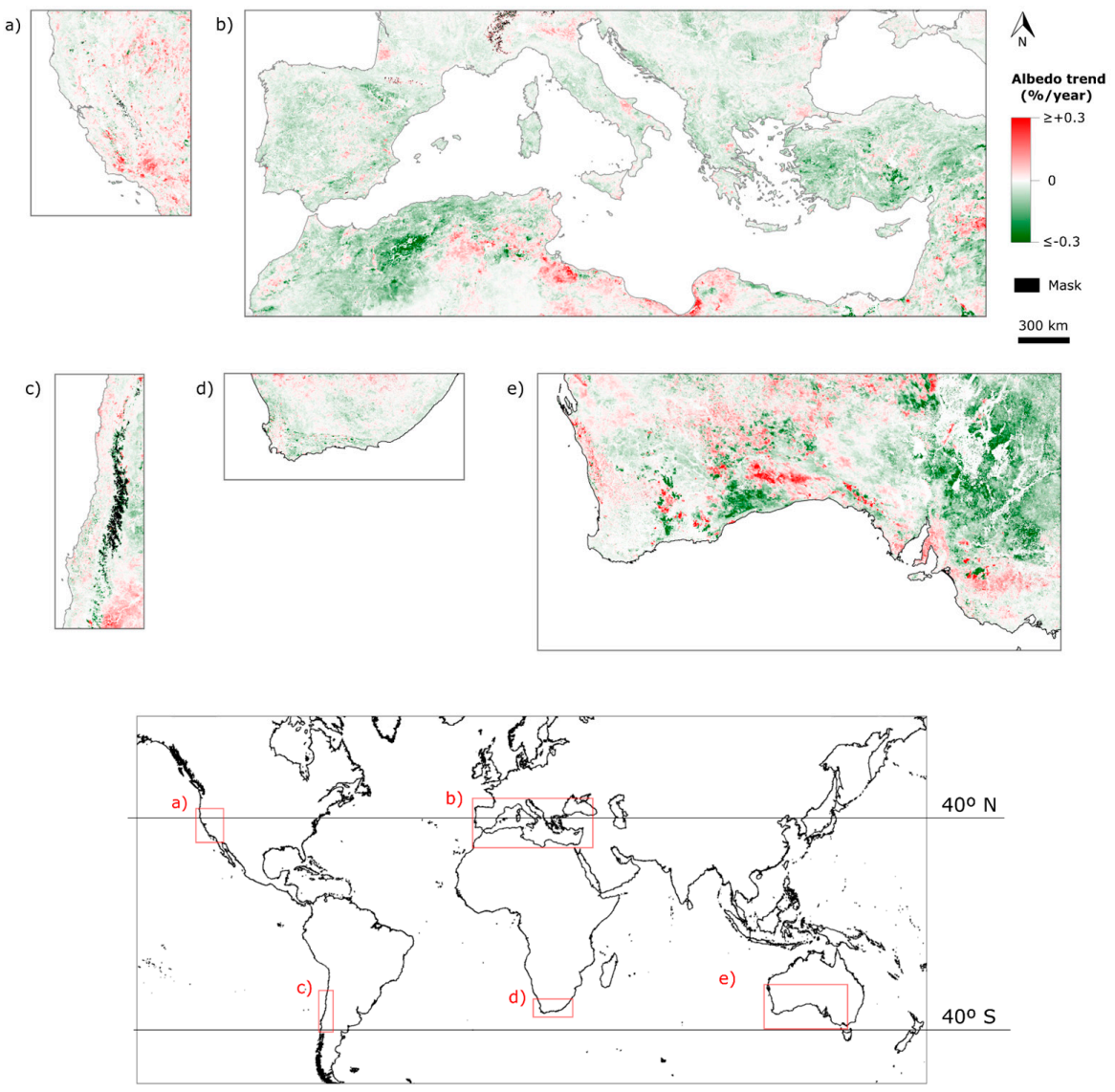

Figure 5. Albedo trend for 2000-2016 in the regions with a Mediterranean climate. The trend depicts the slope, in percentage per year, obtained by fitting a linear regression to the monthly average for June (Northern Hemisphere) and December (Southern Hemisphere) of the MODIS product MCD43A3.006; albedo in the visible part of the spectrum. Negative trends (green) indicate an increase in biomass, and distinct red areas indicate sudden changes such as wildfires. (a) California, (b) Mediterranean basin, (c) Chile, (d) South Africa, and (e) Australia 


\section{The Effects on Ecosystem Services}

Ecosystem services provide a natural capital that does not require the direct human work to build it [214]. Mediterranean ecosystems are suppliers of multiple provision, regulating, cultural and supporting services. As provision tools, forests and other Mediterranean ecosystems such as shrublands, grasslands or agroforestry systems supply goods such as food, medicines, renewable wood products and other goods (e.g., pasture, cork, pine cones and mushrooms) [215]. Mediterranean forests also provide several regulating services such as the protection of soil against erosion, the storage of $C$, and the regulation of atmospheric composition, climate, water and biogeochemical cycles $[215,216]$. They also provide supporting services such as: the maintenance of biodiversity and habitat supply for native fauna. The most important cultural and social functions are the recreational, educational and leisure uses, opportunities for research, their traditional cultural and emotional values and the esthetics of pleasant landscapes, which give rise to important economic activities such as tourism and hiking [217]. Among these features and ecosystem services, the water resources and the storage of $\mathrm{C}$ are especially important for their implications in all these services, because they are the basis of the primary production that supports the services and because of the effects they have on climate change [218]. All previously discussed, global changes will clearly have an impact on many of these goods and services and will therefore affect socioeconomic systems [6].

At the European scale, the risks of drought and disturbance are projected to increase in forests across southern Europe, and the risk of drought is projected to increase from east to west [219]. All climatic models project future scenarios of general decreases in river flows and increases in oscillations of flow intensity in the Mediterranean Basin [220]. The increased environmental presence of emerging pollutants can also impact on forests and their services such as food and water quality [130,221-223]. This is already occurring and can even increase in the immediate future, thus diminishing the provision of clean water and hydroelectric production, with unpredictable socio-economic consequences [130]. The degradation of and decrease in water resources are currently more intense, with the poorest projections for non-perennial Mediterranean rivers in the driest areas of southern Europe [224]. Catchment experiments in a Mediterranean forest showed that there is an increase of carbon and nutrient losses by leaching and erosion after rainfalls following drought periods [225].

The intensification of agriculture for increasing crop productivity has been adopted in many countries in the northern Mediterranean Basin. This intensification has triggered concerns about the future and sustainability of the crop practices in these areas whose water resources are already overexploited [226]. The decrease in water availability for economic growth and the increase in population are key problems needing resolution in most Mediterranean areas.

\subsection{Storage}

The condition of forest crowns in the Mediterranean Basin deteriorated between 1987-2007 [129]. The defoliation was associated mainly with drought due to climate change and paralleled significant increases in tree mortality, a reduction in tree density and changes in insect and fungal dynamics [129]. The health and relative (per unit of surface area) capacity of forests to fix $C$ have thus decreased, despite the increase in the percentage of total area occupied by forests, mainly in the second half of the 20th century [147]. Negative net primary production becomes even more negative when drought coincides with high defoliation in Mediterranean woodlands $[227,228]$. This negative impact of drought on C-sink capacity is stronger in ecosystems with a higher capacity to accumulate biomass, such as forests, than in those with a lower capacity, such as grasslands [229]. Both experimental and observational studies suggest that the increasing drought will decrease the C-storage capacity of forests in the Mediterranean region, mainly those with higher biomasses that can even change from sinks to sources of $\mathrm{CO}_{2}$, such as forests. 


\subsection{Forest Services}

As an economic and socially relevant service, forests in several areas of the Mediterranean Basin are sources for the collection of mushrooms, and some studies have reported that fungal productivity in Mediterranean forests is one of the most sensitive variables that is becoming negatively affected by increased aridity $[230,231]$. The reduction of atmospheric dust pollution and the purification of air by forests are other increasingly important forest services, especially near or in the large urban areas that are continuously growing [232].

Extensive grazing activities that play an important role in rural development and that have traditionally shaped highly valued ecosystem services of different types, such as the dehesas in the Iberian Peninsula, must confront an increasing risk of drought. A recent study of time series between 1999 and 2010 indicated that the risk of a climatic shock on dehesa would be associated with an increase in the frequency of dry springs and dry periods at the beginning of autumn, whereas prolonged periods with delayed precipitation (3-4 weeks) would increase the risk of economic losses [233].

\subsection{Biodiversity}

The high biodiversity of forests in Mediterranean regions has long attracted scientific attention as a conservation service. All Mediterranean regions have many rare and locally endemic taxa that survive as small populations, many of which are threatened by habitat transformation and climate change [234]. Observational and experimental studies that have investigated the effects of drought and aridity on Mediterranean plant communities have detected some degree of decrease in plant-community biomass and species diversity $[107,235,236]$, including lower seedling survival and diversity of seedling recruitment $[237,238]$. The effects of drought on animal communities have been less well studied, but decreases in diversity in response to drought have also been detected [239]. Drought has also decreased the biomass and diversity of soil biota, also favored by the decrease in species diversity at the level of litter production, because the negative effects of drought on litter decomposition is mitigated more as the complexity of the litter increases at the species level $[240,241]$. Jucker et al. [242] have observed that mixed pine-oak forests are favored under moderate drought; shade-intolerant Pinus species received more light and were able to grow $138-155 \%$ faster when mixed with oaks, and oaks were less responsive to mixing due to their tolerance to shade and water shortage. The aboveground net production of wood under these conditions is higher than in mono-stands of either species. The growth of Pinus strongly decreases when drought intensity increases competition for water with the neighboring oaks. A favorable transformation from mixed pine-oak stands to pure oak stands can thus be expected under drought [242], so management favoring mixed pine-oak stands will become more difficult under the projected scenarios of drought.

Semi-arid Mediterranean areas of shrubland and grassland in southern California are affected by increasing anthropogenic $\mathrm{N}$ loads due to the continuous growth of urban areas and by increases in drought frequency and duration [243]. This scenario should favor the replacement of native with invasive species and a general decrease in plant diversity, as recently observed by Vourtilis (2017) [243]. $\mathrm{N}$ deposition in the Mediterranean Basin has produced a continuous increase in nitrophylic plant species, such as those detected in the Iberian Peninsula between 1900 and 2008 [244]. The decrease in the diversity and cover of plant communities due to drought can even be larger when drought coincides with extensive agricultural grazing [176].

Long-term adaptation and evolution in drought environments in Mediterranean ecosystems, however, are unique, because they combine high long-term variability in rainfall and long-term grazing pressure, which have produced a vegetation that is highly resistant to inter-annual fluctuations in growing conditions that can contribute to its persistence under projected increases in drought in Mediterranean regions [245]. This capacity to resist drought has even been demonstrated within species. Thiel et al. [246] observed that Fagus sylvatica L. genotypes in southern Europe were more resistant to drought than those in central and northern Europe, which could help southern European populations to resist future drought. 


\section{The Role of Management and Economy}

The Mediterranean forests have been historically modified by fires, humans (along with their cattle and tools), and most recently by climate and global change. The dynamics of forests can be understood as a series of responses and feedbacks to anthropogenic activities and systems. Both overexploitation and comprehensive protection can decrease the appeal and economic utility of these terrestrial ecosystems.

Drought and its associated degradation are the causes of most problems in Mediterranean areas, so all future plans of land use should take into account droughts' impacts on the water cycle while considering future scenarios of more droughts and fewer water resources [247]. Appropriate revegetation is the main way to stop desertification where it has already occurred. Afforestation with Aleppo pine, or first with appropriate shrubs that can act as nursery species for pines [193,248], but also with shrub species [249], have been successful management strategies, because the first objective is to stop soil degradation rather than to re-establish native vegetation. Chirino et al. [250] observed an effective trade-off between afforestation to stop desertification and the loss of biodiversity of understory vegetation under pines, but the key goal is to stop soil losses to ultimately further repopulate with other species. Ribeiro et al. [251] demonstrated the suitability of this type of strategy to conserve the traditional economy based on extensive exploitation and conservation of a diverse landscape and even to increase the diversity of grasslands and their value as grazing services. Reforestation strategies can be improved, increasing their chance of success, by combining appropriate species reforestation with soil improvements such as the use of biochar [252]. Moreover, an initial repopulation with shrubs such as Myrtus communis L. followed by planting oak trees has been successful in areas still conserved but threatened by further degradation by, for example, increasing drought or difficult regeneration, as in several dehesas in the Iberian Peninsula [253]. In fact, revegetation with shrubs can generally be a useful tool and can further allow reforestation with trees [249].

A representative and wide network of protected areas (i.e., National Parks) has been a robust tool for conserving natural Mediterranean vegetation; the areas remain as refuges for several species and are cradles of diversity that can aid the expansion of natural vegetation under appropriate management policies [254]. The application of more sophisticated models, incorporating terrestrial ecosystem structure, ecosystem-service values at geographic scales and influencing factors such as climate, human activities and other variables, can provide very useful guidelines for making appropriate decisions to preserve the quality and quantity of ecosystem services as best as possible $[255,256]$.

Much can be learned from experiences in California, where efforts to adapt Mediterranean ecosystems to global change and especially to increased aridity are more advanced and where several initiatives to improve the resistance and resilience of Mediterranean forests, shrublands and grasslands to climate but also to other drivers of global change have already begun [257]. Most of these initiatives are based on previous scientific studies and are conducted by the creation of several foundations that obtain, mobilize and drive economic resources to various objectives such as the attainment of management programs for particular ranches and the acquisition of land to implement protection programs. Some promising and successful results have already been attained that preserve and protect the most important ecosystem services, such as biodiversity, water storage or soil quality, which can be effectively defended against global change with appropriate methods based on scientific knowledge and technical applications [257]. These initiatives are consistent with the need to base management strategies on both the knowledge generated by previous scientific studies and on modern and appropriate technologies [258-260], with as much social support as possible [261]).

The management of forests for coping with climate and global change should consider the following:

- Management of disturbed forests, reforestation and "afforestation" of abandoned farmland must incorporate the changes of environmental conditions when defining the intensity and frequency 
of intervention. The decreasing availability of water due to lower rainfall and higher potential evapotranspiration are priorities. For example, the reduction in the densities of stems in dense forests has been an effective measure to reduce the impact of extreme drought.

- The management of forested areas, and natural areas in general, must incorporate the landscape and large-scale planning that considers the combination of mosaics of diverse types, their multiple uses and the effect of disturbances, such as forest fires.

- Research policies and inventories of resources should try to quantify the $C$ in soils and aboveand belowground biomass, because these data are scarce but necessary.

- Reforestation, afforestation post-fire periods should be managed to mitigate climate change by increasing uptake and decreasing the loss of $\mathrm{CO}_{2}$ by prolonging the immobilization of $\mathrm{C}$ in forest products and protecting soils, taking into account the alterations in the water and nutrient cycles that these measures would cause (e.g., Marañón-Jiménez and Castro, 2013 [262]).

- Coordinating research with environmental monitoring networks, compiling extensive databases and solid modelling are urgently needed to determine the degree of pollution in Mediterranean areas and to combine this information with that for climate change [53,153].

- Multi-use strategies for the management and rehabilitation of forests require a large effort in education, research, use and improvement of technical methodologies and economic governance that will allow us to continue to enjoy their services and to gain insight into the potential future changes. These strategies are needed to protect environmental services provided by forests. Society should evolve to accept an economic cost to the successful achievement of these new polices.

\section{Socio-Economic Perspectives}

Soil losses, desertification, increase of fires, torrential rains, or overexploitation of water resources are all associated with increasing drought, human population growth and land-use changes and are real current threats to Mediterranean forests, despite their large capacity to adapt to global change. Populations in the areas affected most by degradation are increasingly giving great importance to the environmental and social use of natural areas, such as the remaining forests. Finding suitable methods of management that protect the remaining forests and other natural communities thus emerges as a new social concern $[210,263]$. The perception of the link between the main economic uses, such as tourism and intensive agriculture, with these environmental problems, however, has not yet become global, nor is it comprehended by large segments of the population [264]. Social studies in southern Spain have observed that a significant part of the population has begun to support an economic cost for the better protection of ecosystems, at least the most emblematic $[210,265]$. This change in attitude has also been observed in Israel [266]. The large trade-off between the current model of tourism, urbanization and intensive agriculture associated with the abandonment of marginal land and the conservation of nature, however, highlights the need to promote new strategies of land management coupled with the prevailing economic model. This task, however, is difficult, because the increasing droughts will likely be even more severe [267], but these caveats can be improved and reverted with an appropriate equilibrium between ecosystem management, economic development and social priorities.

\section{Concluding Remarks}

1. A substantial amount of observational and experimental evidence suggests that climate change together with changes in land-use, pollution, rising atmospheric $\mathrm{CO}_{2}$ concentration and species invasions, has already affected organisms, populations, communities and terrestrial ecosystems in the Mediterranean region.

2. These impacts of global change on Mediterranean organisms and forests are affecting several basic ecosystem services for humans such as provisioning services (supply of renewable natural resources such as pastures, food, medicines or consumer products such as timber, hunting or 
mushrooms), environmental services (maintenance of biodiversity, regulation of atmospheric composition and climate, conservation of soils and water or $C$ storage) and social services (recreational, educational and leisure uses, traditional cultural values or tourism and hiking).

3. This evidence is based on observations at different scales, from genetic and epigenetic changes to the changes of the entire Mediterranean region (observable in satellite images), through the metabolism of organisms, the demographics of plant and animal populations, the composition of communities and the structure and functioning of forests.

4. Drought is the main concern in Mediterranean areas. It negatively affects most services, from food production (by decreasing water sources for irrigation) to C-storing capacity.

5. These drought-driven alterations can become stronger if climate change, its associated disturbances (e.g., by floods, droughts, heat waves and forest fires) and changes in other components of global change (especially the changes of land use, pollution and overexploitation of resources) continue at current rates or are enhanced.

6. Environmental and forest management policies should take into account all these characteristics of Mediterranean forests and the social, environmental and climatic conditions that are projected for the coming years and decades.

7. Several strategies of appropriate afforestation and more efficient water use may conserve the service capacities of Mediterranean forests in equilibrium with human development. Afforestation (forest colonization) and reforestation with autochtonous tree species, first with appropriate shrubs that can act as nursery species for pines, but also with shrub species, have been successful management strategies, because the first objective is to stop soil degradation rather than to re-establish native vegetation.

8. The management of forested areas, and of natural areas in general, should incorporate a hierarchy of landscape guidelines, including a large-scale plan that considers the combination of areas of different types, multiple users and the effects of perturbations, such as forest fires.

9. The control of pollution in and around large Metropolitan areas such as Los Angeles or Barcelona, where the effects of the deposition of $\mathrm{N}$ and other pollutants have a positive synergistic effect with drought. The strong fragmentation and resulting isolation deteriorating many ecosystem services such as the biodiversity, and the formation of toxic substances such as $\mathrm{O}_{3}$ also merit special attention.

Acknowledgments: We thank the European Research Council ERC SyG-610028 2013-Synergy-grant, IMBALANCE-P, the Spanish project CGL2016-79835-P and the Catalan grant SGR 2014-274 for funding this research.

Author Contributions: J.P. drafted the manuscript and all authors contributed to the review.

Conflicts of Interest: The authors declare no conflicts of interest.

\section{References}

1. Intergovernmental Panel on Climate Change (IPCC). 2013: Summary for Policymakers. In Climate Change 2013: The Physical Science Basis. Contribution of Working Group I to the Fifth Assessment Report of the Intergovernmental Panel on Climate Change; Cambridge University Press: Cambridge, UK; New York, NY, USA, 2013; pp. 1-30.

2. Peñuelas, J.; Filella, I.; Sabate, S.; Gracia, C. Natural systems: Terrestrial ecosystems. In Report on Climate Change in Catalonia; Llebot, J.E., Ed.; Institut d'Estudis Catalans: Barcelona, Spain, 2005; pp. 517-553, ISBN 978-84-9965-317-4.

3. Piñol, J.; Terradas, J.; Lloret, F. Climate warming, wildfire hazard, and wilfire occurence in coastal eastern Spain. Int. J. Wildland Fire 1998, 11, 95-106. [CrossRef] 
4. Intergovernmental Panel on Climate Change (IPCC). Climate Change 2014: Impacts, Adaptation and Vulnerability. Part A: Global and Sectoral Aspects. Contribution of Working Group II to the Fifth Assessment Report of the Intergovernmental Panel on Climate Change, 2014; Field, C.B., Barros, V.R., Dokken, D.J., Mach, K.J., Mastrandrea, M.D., Bilir, T.E., Chatterjee, M., Ebi, K.L., Estrada, Y.O., Genova, R.C., et al., Eds.; Cambridge University Press: Cambridge, UK; New York, NY, USA, 2014; ISBN 978-1-107-05807-1.

5. Peñuelas, J.; Sardans, J.; Estiarte, M.; Ogaya, R.; Carnicer, J.; Coll, M.; Barbeta, A.; Rivas-Ubach, A.; Llusià, J.; Garbulsky, M.; et al. Evidence of current impact of climate change on life: A walk from genes to the biosphere. Glob. Chang. Biol. 2013, 19, 2303-2338. [CrossRef] [PubMed]

6. Millennium Ecosystem Assessment. Summary for decision makers. In Ecosystems and Human Well-Being: Synthesis; Island Press: Washington, DC, USA, 2005; pp. 1-24.

7. Peñuelas, J.; Sardans, J.; Filella, I.; Estiarte, M.; Llusià, J.; Ogaya, R.; Carnicer, J.; Bartrons, M.; Rivas-Ubach, A.; Grau, O.; et al. Impactes del canvi climàtic sobre els ecosistemes terrestres catalans. In Tercer Informe sobre el canvi climàtic de Catalunya; Generalitat de Catalunya: Barcelona, Spain, 2016; pp. 211-235, ISBN 9788439394488.

8. Vegas-Vilarrúbia, T.; González-Sampériz, P.; Morellón, M.; Gil-Romera, G.; Pérez-Sanz, A.; Valero-Garcés, B. Diatom and vegetation responses to late glacial and early holocene climate changes at lake estanya (southern pyrenees, NE spain). Palaeogeogr. Palaeoclimatol. Palaeoecol. 2013, 392, 335-349. [CrossRef]

9. Pallàs, R.; Rodés, Á.; Braucher, R.; Carcaillet, J.; Ortuño, M.; Bordonau, J.; Bourlès, D.; Vilaplana, J.M.; Masana, E.; Santanach, P. Late Pleistocene and Holocene glaciation in the Pyrenees: A critical review and new evidence from 10Be exposure ages, south-central Pyrenees. Quat. Sci. Rev. 2006, 25, 2937-2963. [CrossRef]

10. Pla, S.; Catalan, J. Chrysophyte cysts from lake sediments reveal the submillennial winter/spring climate variability in the northwestern Mediterranean region throughout the Holocene. Clim. Dyn. 2005, 24, $263-278$. [CrossRef]

11. Pérez-Sanz, A.; González-Sampériz, P.; Moreno, A.; Valero-Garcés, B.; Gil-Romera, G.; Rieradevall, M.; Tarrats, P.; Lasheras-Álvarez, L.; Morellón, M.; Belmonte, A.; et al. Holocene climate variability, vegetation dynamics and fire regime in the central Pyrenees: The Basa de la Mora sequence (NE Spain). Quat. Sci. Rev. 2013, 73, 149-169. [CrossRef]

12. Revelles, J.; Cho, S.; Iriarte, E.; Burjachs, F.; van Geel, B.; Palomo, A.; Piqué, R.; Peña-Chocarro, L.; Terradas, X. Mid-Holocene vegetation history and Neolithic land-use in the Lake Banyoles area (Girona, Spain). Palaeogeogr. Palaeoclimatol. Palaeoecol. 2015, 435, 70-85. [CrossRef]

13. Carrión, J.S.; Fernández, S.; González-Sampériz, P.; Gil-Romera, G.; Badal, E.; Carrión-Marco, Y.; López-Merino, L.; López-Sáez, J.A.; Fierro, E.; Burjachs, F. Expected trends and surprises in the Lateglacial and Holocene vegetation history of the Iberian Peninsula and Balearic Islands. Rev. Palaeobot. Palynol. 2010, 162, 458-475. [CrossRef]

14. Rull, V.; González-Sampériz, P.; Corella, J.P.; Morellón, M.; Giralt, S. Vegetation changes in the southern Pyrenean flank during the last millennium in relation to climate and human activities: The Montcortès lacustrine record. J. Paleolimnol. 2011, 46, 387-404. [CrossRef]

15. Morellón, M.; Valero-Garcés, B.; González-Sampériz, P.; Vegas-Vilarrúbia, T.; Rubio, E.; Rieradevall, M.; Delgado-Huertas, A.; Mata, P.; Romero, Ó.; Engstrom, D.R.; et al. Climate changes and human activities recorded in the sediments of Lake Estanya (NE Spain) during the Medieval Warm Period and Little Ice Age. J. Paleolimnol. 2011, 46, 423-452. [CrossRef]

16. López-Sáez, J.A.; López-Merino, L.; Mateo, M.Á.; Serrano, Ó.; Pérez-Díaz, S.; Serrano, L. Palaeoecological potential of the marine organic deposits of Posidonia oceanica: A case study in the NE Iberian Peninsula. Palaeogeogr. Palaeoclimatol. Palaeoecol. 2009, 271, 215-224. [CrossRef]

17. Catalan, J.; Pla-Rabés, S.; Wolfe, A.P.; Smol, J.P.; Rühland, K.M.; Anderson, N.J.; Kopáček, J.; Stuchlík, E.; Schmidt, R.; Koinig, K.A.; et al. Global change revealed by palaeolimnological records from remote lakes: A review. J. Paleolimnol. 2013, 49, 513-535. [CrossRef]

18. Cunill, R.; Soriano, J.M.; Bal, M.C.; Pèlachs, A.; Pérez-Obiol, R. Holocene treeline changes on the south slope of the Pyrenees: A pedoanthracological analysis. Veg. Hist. Archaeobotany 2012, 21, 373-384. [CrossRef] 
19. Gonzalez-Samperiz, P.; Aranbarri, J.; Perez-Sanz, A.; Gil-Romera, G.; Moreno, A.; Leunda, M.; Sevilla-Callejo, M.; Corella, J.P.; Morellon, M.; Oliva, B.; et al. Environmental and climate change in the southern Central Pyrenees since the Last Glacial Maximum: A view from the lake records. Catena 2017, 149, 668-688. [CrossRef]

20. Peñuelas, J.; Filella, I.; Comas, P. Changed plant and animal life cycles from 1952 to 2000 in the Mediterranean Region. Glob. Chang. Biol. 2002, 8, 531-544. [CrossRef]

21. Peñuelas, J.; Boada, M. A global-change induced biome shift in the Montseny mountains (NE Spain). Glob. Chang. Biol. 2003, 9, 131-140. [CrossRef]

22. Esteban-Parra, M.J.; Rodrigo, F.S.; Castro-Diez, Y. Spatial and temporal patterns of precipitation in Spain for the period 1880-1992. Int. J. Climatol. 1998, 18, 1557-1574. [CrossRef]

23. McDonald, G.M.; Moser, K.A.; Bloom, A.M.; Potito, A.P.; Porinchu, D.F.; Holmquist, J.R.; Hughes, J.; Kremenetski, K.V. Prolonged California aridity linked to climate warming and Pacific sea surface temperature. Sci. Rep. 2016, 6, 33325. [CrossRef] [PubMed]

24. Lehner, F.; Coats, S.; Stocker, T.F.; Pendergrass, A.G.; Sanderson, B.M.; Raible, C.C.; Smerdon, J.E. Projected drought risk in 1.5 degrees C and 2 degrees C warmer climates. Geophys. Res. Lett. 2017, 44, 7419-7428. [CrossRef]

25. Peñuelas, J.; Ogaya, R.; Boada, M.; Jump, A.S. Migration, invasion and decline: Changes in recruitment and forest structure in a warming-linked shift of European beech forest in Catalonia (NE Spain). Ecography 2007, 30, 829837. [CrossRef]

26. Batllori, E.; Gutiérrez, E. Regional tree line dynamics in response to global change in the Pyrenees. J. Ecol. 2008, 96, 1275-1288. [CrossRef]

27. Jump, A.S.; Hunt, J.M.; Martínez-Izquierdo, J.A.; Penuelas, J. Natural selection and climate change: Temperature-linked spatial and temporal trends in gene frequency in Fagus sylvatica. Mol. Ecol. 2006, 15, 3469-3480. [CrossRef] [PubMed]

28. Jump, A.S.; Hunt, J.M.; Penuelas, J. Rapid climate change-related growth decline at the southern range edge of Fagus sylvatica. Glob. Chang. Biol. 2006, 12, 2163-2174. [CrossRef]

29. Jump, A.S.; Penuelas, J. Genetic effects of chronic habitat fragmentation in a wind-pollinated tree. Proc. Natl. Acad. Sci. USA 2006, 103, 8096-8100. [CrossRef] [PubMed]

30. Jump, A.S.; Penuelas, J.; Rico, L.; Ramallo, E.; Estiarte, M.; Martínez-Izquierdo, J.A.; Lloret, F. Simulated climate change provokes rapid genetic change in the Mediterranean shrub Fumana thymifolia. Glob. Chang. Biol. 2008, 14, 637-643. [CrossRef]

31. Rico, L.; Ogaya, R.; Barbeta, A.; Peñuelas, J. Changes in DNA methylation fingerprint of Quercus ilex trees in response to experimental field drought simulating projected climate change. Plant Biol. 2014, 16, 419-427. [CrossRef] [PubMed]

32. Rivas-Ubach, A.; Sardans, J.; Perez-Trujillo, M.; Estiarte, M.; Penñuelas, J. Strong relationship between elemental stoichiometry and metabolome in plants. Proc. Natl. Acad. Sci. USA 2012, 109, 4181-4186. [CrossRef] [PubMed]

33. Rivas-Ubach, A.; Gargallo-Garriga, A.; Sardans, J.; Oravec, M.; Mateu-Castell, L.; Pérez-Trujillo, M.; Parella, T.; Ogaya, R.; Urban, O.; Peñuelas, J. Drought enhances folivory by shifting foliar metabolomes in Quercus ilex trees. New Phytol. 2014, 202, 874-885. [CrossRef] [PubMed]

34. Rivas-Ubach, A.; Barbeta, A.; Sardans, J.; Guenther, A.; Ogaya, R.; Oravec, M.; Urban, O.; Peñuelas, J. Topsoil depth substantially influences the responses to drought of the foliar metabolomes of Mediterranean forests. Perspect. Plant Ecol. Evol. Syst. 2016, 21, 41-54. [CrossRef]

35. Sardans, J.; Rivas-Ubach, A.; Estiarte, M.; Ogaya, R.; Peñuelas, J. Field-simulated droughts affect elemental leaf stoichiometry in Mediterranean forests and shrublands. Acta Oecol. 2013, 50, 20-31. [CrossRef]

36. Gargallo-Garriga, A.; Sardans, J.; Perez-Trujillo, M.; Rivas-Ubach, A.; Oravec, M.; Vecerova, K.; Urban, O.; Jentsch, A.; Kreyling, J.; Beierkuhnlein, C.; et al. Opposite metabolic responses of shoots and roots to drought. Sci. Rep. 2014, 1-7. [CrossRef] [PubMed]

37. Gargallo-Garriga, A.; Sardans, J.; Oravec, M.; Urban, O.; Jentsch, A.; Kreyling, J.; Beierkuhnlein, C.; Parella, T.; Penuelas, J. Warming differentially influences the effects of drought on stoichiometry and metabolomics in shoots and roots. New Phytol. 2015, 207, 591-603. [CrossRef] [PubMed] 
38. Sardans, J.; Rivas-Ubach, A.; Peñuelas, J. The elemental stoichiometry of aquatic and terrestrial ecosystems and its relationships with organismic lifestyle and ecosystem structure and function: A review and perspectives. Biogeochemistry 2012, 111, 1-39. [CrossRef]

39. Sterner, R.; Elser, J. Ecological Stoichiometry: The Biology of Elements from Molecules to the Biosphere; Princeton University Press: Princeton, NJ, USA, 2002; ISBN 9781400885695.

40. Sardans, J.; Rivas-Ubach, A.; Peñuelas, J. Factors affecting nutrient concentration and stoichiometry of forest trees in Catalonia (NE Spain). For. Ecol. Manag. 2011, 262, 2024-2034. [CrossRef]

41. Sardans, J.; Peñuelas, J. Plant-soil interactions in Mediterranean forest and shrublands: Impacts of climatic change. Plant Soil 2013, 365, 1-33. [CrossRef]

42. Sardans, J.; Peñuelas, J. Drought changes the dynamics of trace element accumulation in a Mediterranean Quercus ilex forest. Environ. Pollut. 2007, 147, 567-583. [CrossRef] [PubMed]

43. Sardans, J.; Peñuelas, J.; Ogaya, R. Drought's impact on Ca, Fe, Mg, Mo and S concentration and accumulation patterns in the plants and soil of a Mediterranean evergreen Quercus ilex forest. Biogeochemistry 2008, 87, 49-69. [CrossRef]

44. Sardans, J.; Peñuelas, J. Tree growth changes with climate and forest type are associated with relative allocation of nutrients, especially phosphorus, to leaves and wood. Glob. Ecol. Biogeogr. 2013, 22, 494-507. [CrossRef]

45. Sardans, J.; Peñuelas, J.; Prieto, P.; Estiarte, M. Drought and warming induced changes in P and K concentration and accumulation in plant biomass and soil in a Mediterranean shrubland. Plant Soil 2008, 306, 261-271. [CrossRef]

46. Sardans, J.; Peñuelas, J.; Estiarte, M.; Prieto, P. Warming and drought alter C and N concentration, allocation and accumulation in a Mediterranean shrubland. Glob. Chang. Biol. 2008, 14, 2304-2316. [CrossRef]

47. Sardans, J.; Peñuelas, J.; Prieto, P.; Estiarte, M. Changes in $\mathrm{Ca}, \mathrm{Fe}, \mathrm{Mg}, \mathrm{Mo}, \mathrm{Na}$, and $\mathrm{S}$ content in a Mediterranean shrubland under warming and drought. J. Geophys. Res. Biogeosci. 2008, 113, 1-11. [CrossRef]

48. Sardans, J.; Peñuelas, J. Soil Enzyme Activity in a Mediterranean Forest after Six Years of Drought. Soil Sci. Soc. Am. J. 2010, 74, 838. [CrossRef]

49. Di Castri, F.; Mooney, H.A. (Eds.) Mediterranean Type Ecosystems: Origin and Structure; Springer: New York, NY, USA, 1973; p. 405.

50. Achotegui-Castells, A.; Sardans, J.; Ribas, À.; Penuelas, J. Identifying the origin of atmospheric inputs of trace elements in the Prades Mountains (Catalonia) with bryophytes, lichens, and soil monitoring. Environ. Monit. Assess. 2013, 185, 615-629. [CrossRef] [PubMed]

51. Díaz-de-Quijano, M.; Penuelas, J.; Ribas, À. Increasing interannual and altitudinal ozone mixing ratios in the Catalan Pyrenees. Atmos. Environ. 2009, 43, 6049-6057. [CrossRef]

52. Kefauver, S.C.; Filella, I.; Penuelas, J. Remote sensing of atmospheric biogenic volatile organic compounds (BVOCs) via satellite-based formaldehyde vertical column assessments. Int. J. Remote Sens. 2014, 35, 7519-7542. [CrossRef]

53. Ochoa-Hueso, R.; Munzi, S.; Alonso, R.; Arróniz-Crespo, M.; Avila, A.; Bermejo, V.; Bobbink, R.; Branquinho, C.; Concostrina-Zubiri, L.; Cruz, C.; et al. Ecological impacts of atmospheric pollution and interactions with climate change in terrestrial ecosystems of the Mediterranean Basin: Current research and fture directions. Environ. Pollut. 2017, 227, 194-206. [CrossRef] [PubMed]

54. Barbeta, A.; Ogaya, R.; Penuelas, J. Dampening effects of long-term experimental drought on growth and mortality rates of a Holm oak forest. Glob. Chang. Biol. 2013, 19, 3133-3144. [CrossRef] [PubMed]

55. Liu, D.; Ogaya, R.; Barbeta, A.; Yang, X.; Penuelas, J. Contrasting impacts of continuous moderate drought and episodic severe droughts on the aboveground-biomass increment and litterfall of three coexisting Mediterranean woody species. Glob. Chang. Biol. 2015, 21, 4196-4209. [CrossRef] [PubMed]

56. Ogaya, R.; Penuelas, J. Phenological patterns of Quercus ilex; Phillyrea latifolia; and Arbutus unedo growing under a field experimental drought. Ecoscience 2004, 11, 263-270. [CrossRef]

57. Ogaya, R.; Barbeta, A.; Başnou, C.; Peñuelas, J. Satellite data as indicators of tree biomass growth and forest dieback in a Mediterranean holm oak forest. Ann. For. Sci. 2015, 72, 135-144. [CrossRef]

58. Barbeta, A.; Mejía-Chang, M.; Ogaya, R.; Voltas, J.; Dawson, T.E.; Penuelas, J. The combined effects of a long-term experimental drought and an extreme drought on the use of plant-water sources in a Mediterranean forest. Glob. Chang. Biol. 2015, 21, 1213-1225. [CrossRef] [PubMed] 
59. Olano, J.M.; Linares, J.C.; García-Cervigón, A.I.; Arzac, A.; Delgado, A.; Rozas, V. Drought-induced increase in water-use efficiency reduces secondary tree growth and tracheid wall thickness in a Mediterranean conifer. Oecologia 2014, 176, 73-83. [CrossRef] [PubMed]

60. Sperlich, D.; Chang, C.T.; Peñuelas, J.; Gracia, C.; Sabaté, S. Foliar photochemical processes and carbon metabolism under favourable and adverse winter conditions in a Mediterranean mixed forest, Catalonia (Spain). Biogeosci. Discuss 2014, 11, 9697-9759. [CrossRef]

61. Sperlich, D.; Chang, C.T.; Peñuelas, J.; Gracia, C.; Sabate, S. Seasonal variability of foliar photosynthetic and morphological traits and drought impacts in a Mediterranean mixed forest. Tree Physiol. 2015, 1-20. [CrossRef] [PubMed]

62. Sperlich, D.; Barbeta, A.; Ogaya, R.; Sabaté, S.; Peñuelas, J. Balance between carbon gain and loss under long-term drought: Impacts on foliar respiration and photosynthesis in Quercus ilex L. J. Exp. Bot. 2016, 67, 821-833. [CrossRef] [PubMed]

63. Peñuelas, J.; Filella, I.; Zhang, X.; Llorens, L.; Ogaya, R.; Lloret, F.; Comas, P.; Estiarte, M.; Terradas, J. Complex spatiotemporal phenological shifts as a response to rainfall changes. New Phytol. 2004, 161, 837-846. [CrossRef]

64. Peñuelas, J.; Filella, I. Responses to a warming world. Science 2001, 294, 793-795. [CrossRef] [PubMed]

65. Piao, S.; Tan, J.; Chen, A.; Fu, Y.H.; Ciais, P.; Liu, Q.; Janssens, I.A.; Vicca, S.; Zeng, Z.; Jeong, S.-J.; et al. Leaf onset in the northern hemisphere triggered by daytime temperature. Nat. Commun. 2015, 6, 6911. [CrossRef] [PubMed]

66. Estiarte, M.; Penuelas, J. Alteration of the phenology of leaf senescence and fall in winter deciduous species by climate change: Effects on nutrient proficiency. Glob. Chang. Biol. 2015, 21, 1005-1017. [CrossRef] [PubMed]

67. Llusià, J.; Penuelas, J.; Alessio, G.; Estiarte, M. Seasonal contrasting changes of foliar concentrations of terpenes and other volatile organic compound in four dominant species of a Mediterranean shrubland submitted to a field experimental drought and warming. Physiol. Plant. 2006, 127, 632-649. [CrossRef]

68. Peñuelas, J.; Staudt, M. BVOCs and global change. Trends Plant Sci. 2010, 15, 133-144. [CrossRef] [PubMed]

69. Peñuelas, J.; Llusià, J. BVOCs: Plant defense against climate warming? Trends Plant Sci. 2003, 8, $105-109$. [CrossRef]

70. Achotegui-Castells, A.; Della Rocca, G.; Llusià, J.; Danti, R.; Barberini, S.; Bouneb, M.; Simoni, S.; Michelozzi, M.; Penuelas, J. Terpene arms race in the Seiridium cardinal—Cupressus sempervirens pathosystem. Sci. Rep. 2016, 6, 18954. [CrossRef] [PubMed]

71. Llusià, J.; Penuelas, J. Emission of volatile organic compounds by apple trees under spider mite attack and attraction of predatory mites. Exp. Appl. Acarol. 2001, 25, 65-77. [CrossRef] [PubMed]

72. Farré-Armengol, G.; Filella, I.; Llusia, J.; Penuelas, J. Relationships among floral VOC emissions, floral rewards and visits of pollinators in five plant species of a Mediterranean shrubland. Plant Ecol. Evol. 2015, 148, 90-99. [CrossRef]

73. Farré-Armengol, G.; Filella, I.; Llusià, J.; Penuelas, J. Pollination mode determines floral scent. Biochem. Syst. Ecol. 2015, 61, 44-53. [CrossRef]

74. Farré-Armengol, G.; Filella, I.; Llusià, J.; Niinemets, Ü.; Penuelas, J. Changes in floral bouquets from compound-specific responses to increasing temperatures. Glob. Chang. Biol. 2014, 3660-3669. [CrossRef] [PubMed]

75. Farré-Armengol, G.; Filella, I.; Llusia, J.; Penuelas, J. Floral volatile organic compounds: Between attraction and deterrence of visitors under global change. Perspect. Plant Ecol. Evol. Syst. 2013, 15, 56-67. [CrossRef]

76. Llusià, J.; Penuelas, J. Seasonal patterns of terpene content and emission from seven Mediterranean woody species in field conditions. Am. J. Bot. 2000, 87, 133-140. [CrossRef] [PubMed]

77. Llusià, J.; Penuelas, J.; Alessio, G.; Estiarte, M. Contrasting species-specific, compound-specific, seasonal, and interannual responses of foliar isoprenoid emissions to experimental droght in a Mediterranean shrubland. Int. J. Plant Sci. 2008, 169, 637-645. [CrossRef]

78. Alessio, G.A.; Penuelas, J.; De Lillis, M.; Llusià, J. Implications of foliar terpene content and hydration on leaf flammability of Quercus ilex and Pinus halepensis. Plant Biol. 2008, 10, 123-128. [CrossRef] [PubMed]

79. Alessio, G.A.; Penuelas, J.; Llusià, J.; Ogaya, R.; Estiarte, M.; De Lillis, M. Influence of water and terpenes on flammability in some dominant Mediterranean species. Int. J. Wildland Fire 2008, 17, 274-286. [CrossRef] 
80. Filella, I.; Penuelas, J. Daily, weekly and seasonal relationships among VOCs, $\mathrm{NOx}_{\text {and }} \mathrm{O}_{3}$ in a semi-urban area near Barcelona. J. Atmos. Chem. 2006, 54, 189-201. [CrossRef]

81. Filella, I.; Penuelas, J. Daily, weekly, and seasonal time courses of VOC concentrations in a semi-urban area near Barcelona. Atmos. Environ. 2006, 40, 7752-7769. [CrossRef]

82. Llusia, J.; Bermejo-Bermejo, V.; Calvete-Sogo, H.; Penuelas, J. Decreased rates of terpene emissions in Ornithopus compressus L. and Trifolium striatum L. by ozone exposure and nitrogen fertilization. Environ. Pollut. 2014, 194, 69-77. [CrossRef] [PubMed]

83. Bellard, C.; Bertelsmeier, C.; Leadley, P.; Thuiller, W.; Courchamp, F. Impacts of climate change on the future of biodiversity. Ecol. Lett. 2012, 15, 365-377. [CrossRef] [PubMed]

84. West-Eberhard, M.J. Phenotypic Plasticity and the Origins of Diversity. Annu. Rev. Ecol. Syst. 1989, 20, $249-278$. [CrossRef]

85. Nylin, S.; Gotthard, K. Plasticity in Life-History Traits. Annu. Rev. Entomol. 1998, 43, 63-83. [CrossRef] [PubMed]

86. Via, S.; Gomulkievicz, R.; De Jong, G.; Scheiner, S.; Schlichting, C.; Van-Tienderen, P. Adaptive phenotypic plasticity: Consensus and controversy. Trends Ecol. Evol. 1995, 10, 212-217. [CrossRef]

87. Charmantier, A.; McCleery, R.H.; Cole, L.R.; Kruuk, L.E.B.; Sheldon, B.C.; Perrins, C. Adaptive Phenotypic Plasticity in Response to Climate Change in a Wild Bird Population. Science 2008, 320, 800-803. [CrossRef] [PubMed]

88. Parmesan, C. Ecological and Evolutionary Responses to Recent Climate Change. Annu. Rev. Ecol. Evol. Syst. 2006, 37, 637-669. [CrossRef]

89. Gordo, O.; Brotons, L.; Ferrer, X.; Comas, P. Do changes in climate patterns in wintering areas affect the timing of the spring arrival of trans-Saharan migrant birds? Glob. Chang. Biol. 2005, 11, 12-21. [CrossRef]

90. Stefanescu, C.; Peñuelas, J.; Filella, I. Effects of climatic change on the phenology of butterflies in the northwest Mediterranean Basin. Glob. Chang. Biol. 2003, 9, 1494-1506. [CrossRef]

91. Donoso, I.; Stefanescu, C.; Martínez-Abraín, A.; Traveset, A. Phenological asynchrony in plant-butterfly interactions associated with climate: A community-wide perspective. Oikos 2016, 1434-1444. [CrossRef]

92. Bonal, R.; Hernandez, M.; Espelta, J.M.; Munoz, A.; Aparicio, J.M. Unexpected consequences of a drier world: Evidence that delay in late summer rains biases the population sex ratio of an insect. R. Soc. Open Sci. 2015, 2, 150198. [CrossRef] [PubMed]

93. Chen, I. Rapid Range Shifts of Species. Science 2011, 333, 1024-1026. [CrossRef] [PubMed]

94. Devictor, V.; van Swaay, C.; Brereton, T.; Brotons, L.; Chamberlain, D.; Heliölä, J.; Herrando, S.; Julliard, R.; Kuussaari, M.; Lindström, A.; et al. Differences in the climatic debts of birds and butterflies at a continental scale. Nat. Clim. Chang. 2012, 2, 121-124. [CrossRef]

95. Bradshaw, W.E.; Holzapfel, C.M. Genetic shift in photoperiodic response correlated with global warming. Proc. Natl. Acad. Sci. USA 2001, 98, 14509-14511. [CrossRef] [PubMed]

96. Carnicer, J.; Wheat, C.; Vives, M.; Ubach, A.; Domingo, C.; Nylin, S.; Stefanescu, C.; Vila, R.; Wiklund, C.; Penuelas, J. Evolutionary Responses of Invertebrates to Global Climate Change: The Role of Life-History Trade-Offs and Multidecadal Climate Shifts. In Global Climate Change and Terrestrial Invertebrates, 1st ed.; Johnson, S.N., Jones, T.H., Eds.; John Wiley \& Sons, Ltd.: Hoboken, NJ, USA, 2017; Chapter 16, ISBN 978-1-119-07090-0.

97. De Frenne, P.; Rodríguez-Sánchez, F.; Coomes, D.A.; Baeten, L.; Verstraeten, G.; Vellend, M.; Bernhardt-Römermann, M.; Brown, C.D.; Brunet, J.; Cornelis, J.; et al. Microclimate moderates plant responses to macroclimate warming. Proc. Natl. Acad. Sci. USA 2013, 110, 18561-18565. [CrossRef] [PubMed]

98. Stefanescu, C.; Carnicer, J.; Peñuelas, J. Determinants of species richness in generalist and specialist Mediterranean butterflies: The negative synergistic forces of climate and habitat change. Ecography 2011, 34, 353-363. [CrossRef]

99. Suggitt, A.J.; Stefanescu, C.; Páramo, F.; Oliver, T.; Anderson, B.J.; Hill, J.K.; Roy, D.B.; Brereton, T.; Thomas, C.D.; Hitch, A.T.; et al. Habitat associations of species show consistent but weak responses to climate. Biol. Lett. 2012, 8, 590-593. [CrossRef] [PubMed]

100. Urban, M.C.; Zarnetske, P.L.; Skelly, D.K. Moving forward: Dispersal and species interactions determine biotic responses to climate change. Ann. N. Y. Acad. Sci. 2013, 1297, 44-60. [CrossRef] [PubMed]

101. Hoffmann, A.; Sgrò, C. Climate change and evolutionary adaptation. Nature 2011, 470, 479-485. [CrossRef] [PubMed] 
102. Carnicer, J.; Stefanescu, C.; Vila, R.; Dincă, V.; Font, X.; Penuelas, J. A unified framework for diversity gradients: The adaptive trait continuum. Glob. Ecol. Biogeogr. 2013, 22, 6-18. [CrossRef]

103. Urban, M. Accelerating extinction risk from climate change. Science 2015, 348, 571-573. [CrossRef] [PubMed]

104. Carnicer, J.; Brotons, L.; Stefanescu, C.; Penuelas, J. Biogeography of species richness gradients: Linking adaptive traits, demography and diversification. Biol. Rev. 2012, 87, 457-479. [CrossRef] [PubMed]

105. Carnicer, J.; Coll, M.; Pons, X.; Ninyerola, M.; Vayreda, J.; Penuelas, J. Large-scale recruitment limitation in Mediterranean pines: The role of Quercus ilex and forest successional advance as key regional drivers. Glob. Ecol. Biogeogr. 2014, 23, 371-384. [CrossRef]

106. Ogaya, R.; Peñuelas, J. Tree growth, mortality, and above-ground biomass accumulation in a holm oak forest under a five-year experimental field drought. Plant Ecol. 2007, 189, 291-299. [CrossRef]

107. Prieto, P.; Peñuelas, J.; Lloret, F.; Llorens, L.; Estiarte, M. Experimental drought and warming decrease diversity and slow down post-fire succession in a Mediterranean shrubland. Ecography 2009, 32, 623-636. [CrossRef]

108. Peñuelas, J.; Llusia, J.; Estiarte, M. Terpenoids a plant language. Tree 1995, 10, 289. [CrossRef]

109. Llusia, J.; Roahtyn, S.; Yakir, D.; Rotenberg, E.; Seco, R.; Guenther, A.; Penuelas, J. Photosynthesis, stomatal conductance and terpene emission response to water availability in dry and mesic Mediterranean forests. Trees 2015, 30, 749. [CrossRef]

110. Filella, I.; Wilkinson, M.J.; Llusià, J.; Hewitt, C.N.; Penuelas, J. Volatile organic compounds emissions in Norway spruce (Picea abies) in response to temperature changes. Physiol. Plant. 2007, 130, 58-66. [CrossRef]

111. Llusià, J.; Penuelas, J.; Munné-Bosch, S. Sustained accumulation of methyl salicylate alters antioxidant protection and reduces tolerance of holm oak to heat stress. Physiol. Plant. 2005, 124, 353-361. [CrossRef]

112. Peñuelas, J.; Llusià, J. The complexity of factors driving volatile organic compound emissions by plants. Biol. Plant. 2001, 44, 481-487. [CrossRef]

113. Farré-Armengol, G.; Filella, I.; Llusia, J.; Primante, C.; Penuelas, J. Enhanced emissions of floral volatiles by Diplotaxis erucoides (L.) in response to folivory and florivory by Pieris brassicae (L.). Biochem. Syst. Ecol. 2015, 63, 51-58. [CrossRef]

114. Filella, I.; Bosch, J.; Llusià, J.; Penuelas, A.; Penuelas, J. Chemical cues involved in the attraction of the oligolectic bee Hoplitis adunca to its host plant Echium vulgare. Biochem. Syst. Ecol. 2011, 39, 498-508. [CrossRef]

115. Filella, I.; Bosch, J.; Llusià, J.; Seco, R.; Penuelas, J. The role of Frass and Cocoon Volatiles in Host Location by Monodontomerus aeneus, a Parasitoid of Megachilid Solitary Bees. Environ. Entomol. 2011, 40, 126-131. [CrossRef] [PubMed]

116. Peñuelas, J.; Farré-Armengol, G.; Llusia, J.; Gargallo-Garriga, A.; Rico, L.; Sardans, J.; Terradas, J.; Filella, I. Removal of floral microbiota reduces floral terpene emissions. Sci. Rep. 2014, 4, 6727. [CrossRef] [PubMed]

117. Llusià, J.; Penuelas, J.; Gimeno, B.S. Seasonal and species-specific response of VOC emissions by Mediterranean woody plant to elevated ozone concentrations. Atmos. Environ. 2002, 36, 3931-3938. [CrossRef]

118. Peñuelas, J.; Llusià, J. Short-term responses of terpene emission rates to experimental changes of PFD in Pinus halepensis and Quercus ilex in summer field conditions. Environ. Exp. Bot. 1999, 42, 61-68. [CrossRef]

119. Farré-Armengol, G.; Penuelas, J.; Li, T.; Yli-Pilrilä, P.; Filella, I.; Llusia, J.; Blande, J.D. Ozone degrades floral scent and reduces pollinator attraction to flowers Ozone degrades floral scent and reduces pollinator attraction to flowers. New Phytol. 2016, 209, 152-160. [CrossRef] [PubMed]

120. Bartrons, M.; Catalan, J.; Peñuelas, J. Spatial and Temporal Trends of Organic Pollutants in Vegetation from Remote and Rural Areas. Sci. Rep. 2016, 6, 25446. [CrossRef] [PubMed]

121. Porta, M.; Gasull, M.; Puigdomenech, E.; Gari, M.; de Basea, M.B.; Guillen, M.; Lopez, T.; Bigas, E.; Pumarega, J.; Llebaria, X.; et al. Distribution of blood concentrations of persistent organic pollutants in a representative sample of the population of Catalonia. Environ. Int. 2010, 36, 655-664. [CrossRef] [PubMed]

122. Meijer, S.N.; Ockenden, W.A.; Sweetman, A.; Breivik, K.; Grimalt, J.O.; Jones, K.C. Global distribution and budget of PCBs and HCB in background surface soils: Implications for sources and environmental processes. Environ. Sci. Technol. 2003, 37, 667-672. [CrossRef] [PubMed]

123. Ma, J.; Hung, H.; Tian, C.; Kallenborn, R. Revolatilization of persistent organic pollutants in the Arctic induced by climate change. Nat. Clim. Chang. 2011, 1, 255-260. [CrossRef] 
124. Carrera, G.; Fernández, P.; Grimalt, J.O.; Ventura, M.; Camarero, L.; Catalan, J.; Nickus, U.; Thies, H.; Psenner, R. Atmospheric deposition of organochlorine compounds to remote high mountain lakes of Europe. Environ. Sci. Technol. 2002, 36, 2581-2588. [CrossRef] [PubMed]

125. Lamon, L.; Von Waldow, H.; Macleod, M.; Scheringer, M.; Marcomini, A.; Hungerbühler, K. Modeling the global levels and distribution of polychlorinated biphenyls in air under a climate change scenario. Environ. Sci. Technol. 2009, 43, 5818-5824. [CrossRef] [PubMed]

126. Bartrons, M.; Grimalt, J.O.; Catalan, J. Altitudinal distributions of BDE-209 and other polybromodiphenyl ethers in high mountain lakes. Environ. Pollut. 2011, 159, 1816-1822. [CrossRef] [PubMed]

127. Bartrons, M.; Gratton, C.; Spiesman, B.J.; Vander Zanden, M.J. Taking the trophic bypass: Aquatic-terrestrial linkage reduces methylmercury in a terrestrial food web. Ecol. Appl. 2015, 25, 151-159. [CrossRef] [PubMed]

128. Pulkrabová, J.; Suchanová, M.; Tomaniová, M.; Kocourek, V.; Hajšlová, J. Organic pollutants in areas impacted by flooding in 2002: A 4-year survey. Bull. Environ. Contam. Toxicol. 2008, 81, 299-304. [CrossRef] [PubMed]

129. Carnicer, J.; Coll, M.; Ninyerola, M.; Pons, X.; Sánchez, G.; Penuelas, J. Widespread crown condition decline, food web disruption, and amplified tree mortality with increased climate change-type drought. Proc. Natl. Acad. Sci. USA 2011, 108, 1474-1478. [CrossRef] [PubMed]

130. Bangash, R.F.; Passuello, A.; Sanchez-Canales, M.; Terrado, M.; López, A.; Elorza, F.J.; Ziv, G.; Acuña, V.; Schuhmacher, M. Ecosystem services in Mediterranean river Basin: Climate change impact on water provision end erosion control. Sci. Total Environ. 2013, 458-460, 246-255. [CrossRef]

131. Peñuelas, J.; Lloret, F.; Montoya, R. Severe drought effects on mediterranean woody flora in Spain. For. Sci. 2001, 47, 214-218.

132. Sardans, J.; Peñuelas, J.; Rodà, F. Plasticity of leaf morphological traits, leaf nutrient content, and water capture in the Mediterranean evergreen oak Quercus ilex subsp. ballota in response to fertilization and changes in competitive conditions. Ecoscience 2006, 13, 258-270. [CrossRef]

133. Sardans, J.; Peñuelas, J. Drought changes nutrient sources, content and stoichiometry in the bryophyte Hypnum cupressiforme Hedw. growing in a Mediterranean forest. J. Bryol. 2008, 30, 59-65. [CrossRef]

134. Sardans, J.; Rivas-Ubach, A.; Penuelas, J. The C:N:P stoichiometry of organisms and ecosystems in a changing world: A review and perspectives. Perspect. Plant Ecol. Evol. Syst. 2012, 14, 33-47. [CrossRef]

135. Sardans, J.; Peñuelas, J.; Estiarte, M. Warming and drought alter soil phosphatase activity and soil $\mathrm{P}$ availability in a Mediterranean shrubland. Plant Soil 2006, 289, 227-238. [CrossRef]

136. Peñuelas, J.; Filella, I.; Lloret, F.; Piñol, J.; Siscart, D. Effects of severe drought on water and nitrogen use by Quercus ilex and Phillyrea latifolia. Biol. Plant. 2000, 43, 47-53. [CrossRef]

137. Medina-Villar, S.; Rodríguez-Echeverría, S.; Lorenzo, P.; Alonso, A.; Pérez-Corona, E.; Castro-Díez, P. Impacts of the alien trees Ailanthus altissima (Mill.) Swingle and Robinia pseudoacacia L. on soil nutrients and microbial communities. Soil Biol. Biochem. 2016, 96, 65-73. [CrossRef]

138. De Marco, A.; Arena, C.; Giordano, M.; Virzo De Santo, A. Impact of the invasive tree black locust on soil properties of Mediterranean stone pine-holm oak forests. Plant Soil 2013, 372, 473-486. [CrossRef]

139. Traveset, A.; Brundu, G.; Carta, L.; Mprezetou, I.; Lambdon, P.; Manca, M.; Médail, F.; Moragues, E.; Rodríguez-Pérez, J.; Siamantziouras, A.S.D.; et al. Consistent performance of invasive plant species within and among islands of the Mediterranean basin. Biol. Invasions 2008, 10, 847-858. [CrossRef]

140. Godoy, O.; Castro-Díez, P.; van Logtestijn, R.S.P.; Cornelissen, J.H.C.; Valladares, F. Leaf litter traits of invasive species slow down decomposition compared to Spanish natives: A broad phylogenetic comparison. Oecologia 2010, 162, 781-790. [CrossRef] [PubMed]

141. Noumi, Z. Effects of exotic and endogenous shrubs on understory vegetation and soil nutrients in the south of Tunisia. J. Arid Land 2015, 7, 481-487. [CrossRef]

142. Benesperi, R.; Giuliani, C.; Zanetti, S.; Gennai, M.; Mariotti Lippi, M.; Guidi, T.; Nascimbene, J.; Foggi, B. Forest plant diversity is threatened by Robinia pseudoacacia (black-locust) invasion. Biodivers. Conserv. 2012, 21, 3555-3568. [CrossRef]

143. Lazzaro, L.; Giuliani, C.; Fabiani, A.; Agnelli, A.E.; Pastorelli, R.; Lagomarsino, A.; Benesperi, R.; Calamassi, R.; Foggi, B. Soil and plant changing after invasion: The case of Acacia dealbata in a Mediterranean ecosystem. Sci. Total Environ. 2014, 497-498, 491-498. [CrossRef] [PubMed]

144. González-Muñoz, N.; Costa-Tenorio, M.; Espigares, T. Invasion of alien Acacia dealbata on Spanish Quercus robur forests: Impact on soils and vegetation. For. Ecol. Manag. 2012, 269, 214-221. [CrossRef] 
145. Erskine-Ogden, J.; Grotkopp, E.; Rejmanek, M. Mediterranean, invasive, woody species grow larger than their less-invasive counterparts under potential global environmental change. Am. J. Bot. 2016, 103, 613-624. [CrossRef] [PubMed]

146. Sardans, J.; Alonso, R.; Janssens, I.A.; Carnicer, J.; Vereseglou, S.; Rillig, M.C.; Fernandez-Martinez, M.; Sanders, T.G.M.; Peñuelas, J. Foliar and soil concentrations and stoichiometry of nitrogen and phosphorous across European Pinus sylvestris forests: Relationships with climate, $\mathrm{N}$ deposition and tree growth. Funct. Ecol. 2016, 30, 676-689. [CrossRef]

147. Vayreda, J.; Martínez-Vilalta, J.; Gracia, M.; Canadell, J.G.; Retana, J. Anthropogenic-driven ràpid shifts in tree Distribution lead to increased dominance of broadleaf species. Glob. Chang. Biol. 2016, 22, 3984-3995. [CrossRef] [PubMed]

148. Vilà-Cabrera, A.; Espelta, J.M.; Vayreda, J.; Pino, J. “New Forests” from the twentieth century are a relevant contribution for C storage in the Iberian Peninsula. Ecosystems 2017, 20, 130-143. [CrossRef]

149. San Roman Sanz, A.; Fernández, C.; Mouillot, F.; Ferrat, L.; Istria, D.; Pasqualini, V. Long-term forest Dynamics and land-use abandonament in the Mediterranean mountains, Corsica, France. Ecol. Soc. 2013, 18, 38. [CrossRef]

150. Acácio, V.; Holmgren, M.; Rego, F.; Moreira, F.; Mohren, G.M.J. Are drought and wildfires turning Mediterranean cork oak forest into persistent shrublands? Agrofor. Syst. 2009, 76, 389-400. [CrossRef]

151. Padilla, F.M.; Vidal, B.; Sánchez, J.; Pugnaire, F.I. Land-use changes and carbon sequestration through the twentieth century in a Mediterranean mountain ecosystem: Implications for land management. J. Environ. Manag. 2010, 91, 2688-2695. [CrossRef] [PubMed]

152. Keenan, T.; Serra, J.M.; Lloret, F.; Ninyerola, M.; Sabate, S. Predicting the future of forests in the Mediterranean under climate change, with niche- and process-based models: $\mathrm{CO}_{2}$ matters! Glob. Chang. Biol. 2011, 17, 565-579.

153. Doblas-Miranda, E.; Martínez-Vilalta, J.; Lloret, F.; Álvarez, A.; Ávila, A.; Bonet, F.J.; Brotons, L.; Castro, J.; Curiel-Yuste, J.; Díaz, M.; et al. Reassessing global change research priorities in mediterranean terrestrial ecosystems: How far have we come and where do we go from here? Glob. Ecol. Biogeogr. 2015, 24, $25-43$. [CrossRef]

154. Rao, L.E.; Allen, E.B.; Meixner, T. Risk-baseds determination of critical nitrogen deposition loads for fire spread in Southern California deserts. Ecol. Appl. 2010, 20, 1320-1335. [CrossRef] [PubMed]

155. Khalili, B.; Ogunseitan, O.A.; Goulden, M.L.; Allison, S.D. Interactive effects of precipitation manipulation and nitrogen addition on soil properties in California grassland and shrubland. Appl. Soil Ecol. 2016, 107, 144-153. [CrossRef]

156. Syphard, A.D.; Franklin, J.; Keely, J.E. Simulating the effects of freqüent fire on Southern California coastal shrublands. Ecol. Appl. 2006, 16, 1744-1756. [CrossRef]

157. Parra, A.; Moreno, J.M. Post-fire environaments are favorable for plant functioning of seeder and resprouter Mediterranean shrubs, even under drought. New Phytol. 2017, 214, 1118-1131. [CrossRef] [PubMed]

158. Lloret, F.; Casanovas, C.; Peñuelas, J. Seedling survival of Mediterranean shrubland species in relation to root: Shoot ratio, seed size and wàter and nitrogen use. Funct. Ecol. 1999, 13, 210-216. [CrossRef]

159. Martí-Roura, M.; Casals, P.; Romanyà, J. Long-term retention of post-fire soil mineral nitrogen pools in Mediterranean shrubland and grassland. Plant Soil 2013, 371, 521-531. [CrossRef]

160. Padilla, F.M.; de Dios Miranda, J.; Pugnaire, F.I. Early root growth plasticity in seedlings of three Mediterranean Woody species. Plant Soil 2007, 296, 103-113. [CrossRef]

161. De Dato, G.; Pellizzaro, G.; Cesaraccio, C.; Sirca, C.; De Angelis, P.; Duce, P.; Spano, D.; Scarascia Mugnozza, G. Effects of warmer and drier climate conditions on plant composition and biomass production in a Mediterranean shrubland community. iForest 2008, 1, 39-48. [CrossRef]

162. Prieto, P.; Peñuelas, J.; Ogaya, R.; Estiarte, M. Precipitation-dependent flowering of Globularia alypum and Erica multiflora in Mediterranean shrubland under experimental drought and warming and its inter-annual variability. Ann. Bot. 2008, 102, 275-285. [CrossRef] [PubMed]

163. Prieto, P.; Peñuelas, J.; Llusià, J.; Asensio, D.; Estiarte, M. Effects of long-term experimental night-time warming and drought on photosynthesis, Fv/Fm and stomatal conductance in the dominant species of a Mediterranean shrubland. Acta Physiol. Plant 2009, 31, 729-739. [CrossRef]

164. West, A.G.; Dawson, T.E.; February, E.C.; Midgley, G.F.; Bond, W.J.; Aston, T.L. Diverse funcional responses to drought in a Mediterranean-type shrubland in South Africa. New Phytol. 2012, 195, 396-407. [CrossRef] [PubMed] 
165. Del Cacho, M.; Peñuelas, J.; Lloret, F. Reproductive output in Mediterranean shrubs under climate change experimentally induced by drought and warming. Perspect. Plant Ecol. Evol. Syst. 2013, 15, 319-327. [CrossRef]

166. Lloret, F.; de la Riva, E.G.; Pérez-Ramos, I.M.; Marañon, T.; Saura-Mas, S.; Díaz-Delgado, R.; Villar, R. Climatic events inducing die-off in Mediterranea shrublands: Are species' responses related to their funcional traits? Oecologia 2016, 180, 961-973. [CrossRef] [PubMed]

167. Sapes, G.; Serra-Díaz, J.M.; Lloret, F. Species climàtic niche explanis drought-induced die-off in a Mediterranean Woody community. Ecosphere 2017, 8, e01833. [CrossRef]

168. Dirks, I.; Navon, Y.; Kanas, D.; Dumbur, R.; Grünzweig, J.M. Atmospheric wàter vapor as driver of litter decomposition in Mediterranean shrubland and grassland during rainless seasons. Glob. Chang. Biol. 2010, 16, 2799-2812. [CrossRef]

169. Talmon, Y.; Sternberg, M.; Grünzweig, J.M. Impact of rainfall manipulations and biòtic controls on soil respiration in Mediterranean and desert ecosystems along an aridity gradient. Glob. Chang. Biol. 2011, 17, 1108-1118. [CrossRef]

170. Del Cacho, M.; Saura-Mas, S.; Estiarte, M.; Peñuelas, J.; Lloret, F. Effect of experimentally induced climate change on the seed bank of a Mediterranean shrubland. J. Veg. Sci. 2012, 23, 280-291. [CrossRef]

171. Colombaroli, D.; Marchetto, A.; Tinner, W. Long-term interactions between Mediterranean climate vegetation and fire regime at Logo di Massaciuccoli (Tuscany, Italy). J. Ecol. 2007, 95, 755-770. [CrossRef]

172. Liu, D.; Estiarte, M.; Ogaya, R.; Yang, X.; Peñuelas, J. Shift in community structure in an early-successional Mediterranean shrubland driven by long-term experimental warming and drought and natural extreme droughts. Glob. Chang. Biol. 2017, 23, 4267-4279. [CrossRef] [PubMed]

173. Porqueddu, C.; Ates, S.; Louhaichi, M.; Kyriazopoulos, A.P.; Moreno, G.; del Pozo, A.; Ovalle, C.; Ewing, M.A.; Nichols, P.G.H. Grassland in "Old World" and "New Worls" Mediterranean-climate zones: Past trends, corrent status and future research priorities. Grass Forage Sci. 2016, 71, 1-35. [CrossRef]

174. Golodets, C.; Sternberg, M.; Kigel, J.; Boeken, B.; Henkin, Z.; Seligman, N.G.; Ungar, E.D. From desert to Mediterranean rangelands: Will increasing drought and inter-annual rainfall variability affect herbaceous annual primary productivity? Clim. Chang. 2013, 119, 785-798. [CrossRef]

175. Mamolos, A.P.; Veresoglou, D.S.; Noitsakis, V.; Gerakis, A. Differential drought tolerance of five coexisting plant species in Mediterranean lowland grasslands. J. Arid Environ. 2001, 49, 329-341. [CrossRef]

176. Carmona, C.P.; Azcárate, F.M.; de Bello, F.; Ollero, H.S.; Leps, J.; Peco, B. Taxonomical and funcional diversity turnover in Mediterranean grasslands: Interactions between grazing, habitat type and rainfall. J. Appl. Ecol. 2012, 49, 1084-1093. [CrossRef]

177. Rota, C.; Manzano, P.; Carmona, C.P.; Malo, J.E.; Peco, B. Plant community assenbly in Mediterranean grasslands: Understanding the interplay between grazing and spatio-temporal wàter availability. J. Veg. Sci. 2017, 28, 149-159. [CrossRef]

178. Bonanomi, G.; Incerti, G.; Allegrezza, M. Assessing the impact of land abandonament, nitrogen enrichment and fairy-ring fungi on plant diversity of Mediterranean grassland. Biodivers. Conserv. 2013, 22, 2285-2304. [CrossRef]

179. Jiménez-Alfaro, B.; Gavilán, R.G.; Escudero, A.; Iriondo, J.M.; Fernández-González, F. Decline of dry grassland specialists in Mediterranean high-mountain communities influences by recent climate warming. J. Veg. Sci. 2014, 25, 1394-1404. [CrossRef]

180. Mairota, P.; Leronni, V.; Xi, W.; Mladenoff, D.J.; Nagendra, H. Using spatial simulations of habitat modifications for adaptative management of protected areas: Mediterranean grassland modification by Woody plant encroachment. Environ. Conserv. 2013, 41, 144-156. [CrossRef]

181. Gracia, C.; Burriel, J.A.; Ibàñez, J.J.; Mata, T.; Vayreda, J. Inventari Ecològic i Forestal de Catalunya. Catalunya; Centre for Research on Ecology and Forestry Applications (CREAF): Bellaterra, Spain, 2004; Volume 10, p. 184, ISBN 84-932860-3-6.

182. Keenan, T.; García, R.; Friend, A.D.; Zaehle, S.; Gracia, C.; Sabate, S. Improved understanding of drought controls on seasonal variation in Mediterranean forest canopy $\mathrm{CO}_{2}$ and water fluxes through combined in situ measurements and ecosystem modelling. Biogeosciences 2009, 6, 1423-1444. [CrossRef]

183. Nadal-Sala, D.; Sabaté, S.; Gracia, C. GOTILWA+: Una herramienta para optimizar la gestión forestal adaptada al cambio climático. Ambienta 2014, 108, 106-120. 
184. Gotilwa+: Growth of Trees Is Limited by Water. Available online: www.creaf.uab.cat/gotilwa/ (accessed on 17 November 2017).

185. Nadal-Sala, D.; Sabaté, S.; Gracia, C. The relative importance of soil depth for Aleppo pine (Pinus halepensis Mill.) resilience in face of the increasing aridity promoted by climate change. Ecosistemas 2017, 26, 18-26. [CrossRef]

186. Zhu, B.; Cheng, W. Impacts of drying-wetting cycles on rhizosphere respiration and soil organic matter decomposition. Soil Biol. Biochem. 2013, 63, 89-96. [CrossRef]

187. Verger, A.; Baret, F.; Weiss, M.; Lacaze, R.; Makhmara, H.; Vermote, E. Long term consistent global GEOV1 AVHRR biophysical products. In Proceedings of the 32th EARSeL Symposium on Temporal Analysis of Satellite Images, Mykonos, Greece, 23-25 May 2012; pp. 1-6.

188. Garbulsky, M.F.; Penuelas, J.; Gamon, J.; Inoue, Y.; Filella, I. The photochemical reflectance index (PRI) and the remote sensing of leaf, canopy and ecosystem radiation use efficiencies. A review and meta-analysis. Remote Sens. Environ. 2011, 115, 281-297. [CrossRef]

189. Peñuelas, J.; Filella, I.; Gamon, J. Assessment of plant photosynthetic radiation-use efficiency with spectral reflectance. New Phytol. 1995, 131, 291-296. [CrossRef]

190. Peñuelas, J.; Garbulsky, M.F.; Filella, I. Photochemical reflectance index (PRI) and remote sensing of plant $\mathrm{CO}_{2}$ uptake. New Phytol. 2011, 191, 596-599. [CrossRef] [PubMed]

191. Zhang, C.; Filella, I.; Garbulsky, M.; Peñuelas, J. Affecting Factors and Recent Improvements of the Photochemical Reflectance Index (PRI) for Remotely Sensing Foliar, Canopy and Ecosystemic Radiation-Use Efficiencies. Remote Sens. 2016, 8, 677. [CrossRef]

192. Shakesby, R.A. Post-wildfire soil erosion in the Mediterranean: Review and future research directions. Earth-Sci. Rev. 2011, 105, 71-100. [CrossRef]

193. Safriel, U.N. Status of Desertification in the Mediterranean region. In Water Scarcity, Land Degradation and Desertification in the Mediterranean Region; Rubio, J.L., Safriel, U., Daussa, R., Blum, W., Pedrazzini, F., Eds.; Springer: Berlin/Heidelberg, Germany, 2009; pp. 33-73, ISBN 978-90-481-2526-5.

194. Baeza, M.J.; Valdecantos, A.; Alloza, J.A.; Vallejo, R. Human disturbance and environmental factors as drivers of long-term post-fire regeneration patterns in Mediterranean forest. J. Veg. Sci. 2007, 18, 243-252. [CrossRef]

195. Coelho, C.D.O.A.; Ferreira, A.J.D.; Boulet, A.K.; Keizer, J.J. Overland flow generation processes, erosion yields and solute loss following different intensity fires. Q. J. Eng. Geol. Hydrogeol. 2004, 37, 233-240. [CrossRef]

196. Millan, M.M.; Estrella, M.J.; Sanz, M.J.; Mantilla, E.; Martin, M.; Pastor, F.; Salvador, R.; Vallejo, R.; Alonso, L.; Gangoiti, G.; et al. Climatic feedbacks and desertification: The Mediterranean model. J. Clim. 2005, 18, 684-701. [CrossRef]

197. Zucca, C.; Canu, A.; Della Peruta, R. Effects of land use and landscape on spatial distribution and morphological features of gullies in an agropastoral area in Sardinia (Italy). Catena 2006, 88, 87-95. [CrossRef]

198. Calatrava, J.; Barbera, G.G.; Castillo, V.M. Farming practiques and policy measures for agricultural soil conservation in semi-arid Mediterranean areas: The case of the Guadalentin basin in Southeast Spain. Land Degrad. Dev. 2011, 22, 58-69. [CrossRef]

199. Kéfi, S.; Rietkerk, M.; Alados, C.L.; Pueyo, Y.; Papanastasis, V.P.; Eiaich, A.; de Ruiter, P.C. Spatial vegetation paterns and imminent desertification in Mediterranean arid ecosystems. Nature 2007, 449, $213-217$. [CrossRef] [PubMed]

200. Frei, C.; Schär, C.; Lüthi, D.; Davies, H.C. Heavy precipitation processes in a warmer climate. Geophys. Res. Lett. 1998, 25, 1431-1434. [CrossRef]

201. Romero, R.; Guijarro, J.A.; Ramis, C.; Alonso, S. A 30-year (1964-1993) daily data base for the Spanish Mediterranean regions: First exploratory study. Int. J. Climatol. 1998, 18, 541-560. [CrossRef]

202. International Panel on Climate Change (IPCC). Climate Change 2007: The physical science basis. Contribution of Working Group I. In Fourth Assessment Report of the Intergovernmental Panel on Climate Change; Solomon, S., Qin, D., Manning, M., Chen, Z., Marquis, M., Averyt, K.B., Tignor, M., Miller, H.L., Eds.; Cambridge University Press: Cambridge, UK; New York, NY, USA, 2007; pp. 849-940, ISBN 978-0-521-88009-1.

203. Garcia, C.; Hernandez, T.; Roldan, A.; Martin, A. Effect of plant cover decline on chemical and microbiological parameters under Mediterranean climate. Soil Biol. Biochem. 2002, 34, 635-642. [CrossRef] 
204. García-Fayos, P.; Bochet, E. Indication of antagonistic interaction between climate change and erosion on plant species richness and soil properties in semiàrid Mediterranean ecosystems. Glob. Chang. Biol. 2009, 15, 306-308. [CrossRef]

205. Moreno-de las Heras, M.; Espigares, T.; Merino-Martín, L.; Nicolau, J.M. Water-related ecological impacts of rill erosion processes in Mediterranean-dry reclaimed slopes. Catena 2011, 84, 114-124. [CrossRef]

206. Ruiz-Sinoga, J.D.; Gabarón Galeote, M.A.; Martínez Murillo, J.F.; Garcia Marín, R. Vegetation strategies for soil consumption along a pluviometric gradient in southern Spain. Catena 2011, 84, 12-20. [CrossRef]

207. Grossiord, C.; Granier, A.; Ratcliffe, S.; Bouriaud, O.; Bruelheide, H.; Checko, E.; Forresterg, D.I.; Dawudh, S.M.; Finéri, L.; Pollastrinij, M.; et al. Tree diversity does not always improve resistance of forest ecosystems to drought. Proc. Natl. Acad. Sci. USA 2014, 111, 14812-14815. [CrossRef] [PubMed]

208. González-Hidalgo, J.C.; Peña-Monné, J.L.; de Luís, M. A review of daily soil erosion in Western Mediterranean areas. Catena 2007, 71, 193-199. [CrossRef]

209. Barnes, P.W.; Throop, H.L.; Hewins, D.B.; Abbene, M.L.; Archer, S.R. Soil coverage reduces photodegradation and promotes the development of soil-microbial films on dryland leaf litter. Ecosystems 2012, 15, 311-321. [CrossRef]

210. Riera, P.; Peñuelas, J.; Farreras, V.; Estiarte, M. Valuation of climate-change effects on Mediterranean shrublands. Ecol. Appl. 2007, 17, 91-100. [CrossRef]

211. Weedon, G.P.; Balsamo, G.; Bellouin, N.; Gomes, S.; Best, M.J.; Viterbo, P. The WFDEI meteorological forcing data set: WATCH Forcing Data methodology applied to ERA-Interim reanalysis data. Water. Resour. Res. 2014, 50, 7505-7514. [CrossRef]

212. Vicente-Serrano, S.M.; Beguería, S.; López-Moreno, J.I. A Multiscalar Drought Index Sensitive to Global Warming: The Standardized Precipitation Evapotranspiration Index. J. Clim. 2009, 23, 1696-1718. [CrossRef]

213. Peñuelas, J.; Rutishauser, T.; Filella, I. Phenology Feedbacks on cllimate change. Science 2009, 324, 887-888. [CrossRef] [PubMed]

214. Costanza, R.; de Groot, R.; Braat, L.; Kubiszewski, I.; Fioramonti, L.; Sutton, P.; Farber, S.; Grasso, M. Twenthy years of ecosystenm services: How far have we come and how far do we still need to go? Ecosyst. Serv. 2017, 28, 1-16. [CrossRef]

215. Palahi, M.; Mavsar, R.; Gracia, C.; Birot, Y. Mediterranean forest under focus. Int. For. Rev. 2008, 10, 676-688. [CrossRef]

216. Guerra, C.A.; Maes, J.; Geijzendorffer, I.; Metzger, M.J. An assessment of soil erosion prevention by vegetation in Mediterranean Europe: Current trends of ecosystem service provision. Ecol. Indic. 2016, 60, $213-222$. [CrossRef]

217. Gios, G.; Clauser, O. Forest and tourism: Economic evaluation and management features under sustainable multifunctionality. iForest 2009, 2, 192-197. [CrossRef]

218. Ruiz-Peinado, R.; Bravo-Oviedo, A.; Lopez-Senespleda, E.; Bravo, F.; Del Rio, M. Forest Management and carbón sequestration in the Mediterranean región: A review. For. Syst. 2017, 26, 2. [CrossRef]

219. Lindner, M.; Maroschek, M.; Netherer, S.; Kremer, A.; Barbati, A.; Garcia-Gonzalo, J.; Seidi, R.; Delzon, S.; Corona, P.; Kolström, M.; et al. Climate change impacts, adaptative capacity, and vulnerability of European forest ecosystems. For. Ecol. Manag. 2010, 259, 698-709. [CrossRef]

220. Scheneider, C.; Laizé, C.L.R.; Acreman, M.C.; Flörke, M. How will climate change modify river flow regimes in Europe? Hydrol. Earth Syst. Sci. 2013, 17, 325-339. [CrossRef]

221. Petrovic, M.; Ginebrada, A.; Acuña, V.; Batalla, R.J.; Elosegi, A.; Guasch, H.; López de Alda, M.; Marcé, R.; Muñoz, I.; Navarro-Ortega, A.; et al. Combined scenarios of chewmical and Ecological quality under wàter scarcity in Mediterranean rivers. Trends Anal. Chem. 2011, 30, 1269-1278. [CrossRef]

222. Lutz, S.R.; Mallucci, S.; Diamantini, E.; Mojone, B.; Bellin, A.; Merz, R. Hydroclimatic and wàter quality trends across Mediterranean river basins. Sci. Total Environ. 2016, 571, 1392-1406. [CrossRef] [PubMed]

223. Bartrons, M.; Peñuelas, J. Pharmaceuticals and personal-care products in plants. Trends Plant Sci. 2017, 22, $194-203$. [CrossRef] [PubMed]

224. Skoulikidis, N.T.; Sabater, S.; Datry, T.; Morais, M.M.; Buffagni, A.; Dörflinger, G.; Zogaris, S.; Sánchez-Montoya, A.M.; Bonada, N.; Kalogianni, E.; et al. Non-prennial Mediterranean rivers in Europe: Status, pressures, and challenges for research and management. Sci. Total Environ. 2017, 577, 1-18. [CrossRef] [PubMed] 
225. Piñol, J.; Avila, A.; Rodà, F. The seasonal-variation of stremwater chemistry in 3 forested Mediterranean catchments. J. Hydrol. 1992, 140, 119-141. [CrossRef]

226. Rupérez-Moreno, C.; Senent, J.; Martinez-Vicente, D.; García-Aróstegui, J.L.; Cabezas Calvo-Rubio, F.; Pérez-Sánchez, J. Sustainability of irrigated agriculture with overexploited aquifers: The case of Segura basin (SE, Spain). Agric. Water Manag. 2017, 182, 67-76. [CrossRef]

227. Allard, V.; Ourcival, J.M.; Rambal, S.; Joffre, R.; Rocheteau, A. Seasonal and anual variation of carbon Exchange in an evergreen Mediterranean forest in Southern France. Glob. Chang. Biol. 2008, 14, 714-725. [CrossRef]

228. Lempereur, M.; Martin-StPaul, N.K.; Damesin, C.; Joffre, R.; Ourcival, J.M.; Rocheteau, A.; Rambla, S. Growth duration is a better predictor of stem increment than carbon supply in a Mediterranean oak forest: Implications for assessing forest productivity under climate change. New Phytol. 2015, 207, 579-590. [CrossRef] [PubMed]

229. Pereira, J.S.; Mateus, J.A.; Aires, L.M.; Pita, G.; Pio, C.; David, J.S.; Andrade, V.; Banza, J.; David, T.S.; Paço, T.A.; et al. Net ecosystem carbon Exchange in three contrastin Mediterranean ecosystems-The effect of drought. Biogeosciences 2007, 4, 791-802. [CrossRef]

230. Ogaya, R.; Peñuelas, J. Decreased mushroom production in a holm oak forest in response to an experimental drought. Forestry 2005, 78, 279-283. [CrossRef]

231. Büntgen, U.; Egli, S.; Galvan, D.; Diez, J.M.; Aldea, J.; Latorre, J.; Martínez-Peña, F. Drought-induced changes in the phenology, productivity and diversity of Spanish fungi. Fungal Ecol. 2015, 16, 6-18. [CrossRef]

232. Santos, A.; Pinho, P.; Munzi, S.; Botelho, M.J.; Palma-Oliveira, J.M.; Branquinho, C. The role of forest in mitigating the impact of atmospheric dust pollution in a mixed landscape. Environ. Sci. Pollut. Res. 2017, 24, 12038-12048. [CrossRef] [PubMed]

233. Iglesias, E.; Báez, K.; Diaz-Ambrona, C.H. Assessing drought risk in Mediterranean Dehesa grazing lands. Agric. Syst. 2016, 149, 65-74. [CrossRef]

234. Cowling, R.M.; Rundel, P.W.; Lamont, B.B.; Arroyo, M.K.; Arianoutsou, M. Plant diversity in Mediterranean-climate regions. Trends Ecol. Evol. 1996, 11, 362-366. [CrossRef]

235. Sebastià, M.T.; Kirwan, L.; Connolly, J. Strong shifts in plant diversity and vegetation composition in grassland shortly after climàtic change. J. Veg. Sci. 2008, 19, 299-306. [CrossRef]

236. De la Riva, E.; Lloret, F.; Pérez-Ramos, I.M.; Marañon, T.; Saura-Mas, S.; Díaz-Delgado, R.; Villar, R. The importance of funcional diversity in the stability of Mediterranean shrubland communities after the impacts of extreme climàtic events. J. Plant Ecol. 2017, 2, 281-293. [CrossRef]

237. Lloret, F.; Peñuelas, J.; Estiarte, M. Experimental evidence of reduced diversity of seedlings due to climate modification in a Mediterranean-type community. Glob. Chang. Biol. 2004, 10, 248-258. [CrossRef]

238. Matías, L.; Zamora, R.; Castro, J. Repercussions of simulated climate change on the diversity of Woody-recruit bank in a Mediterranean-type ecosystem. Ecosystems 2011, 14, 672-682. [CrossRef]

239. Legakis, A.; Adamopoulou, C. Temporal responses of soil invertebrate communities to drought stress in two semiarid ecosystems of the Mediterranean. Isr. J. Zool. 2013, 51, 331-348. [CrossRef]

240. Santoja, M.; Fernandez, C.; Proffit, M.; Gers, C.; Gauquelin, T.; Reiter, I.M.; Cramer, W.; Baldy, V. Plant litter mixture partly mitigates the negative effects of extended drought on soil biota and litter decomposition in a Mediterranean oak forest. J. Ecol. 2017, 105, 801-815. [CrossRef]

241. Shihan, A.; Hättenschwiller, S.; Mileu, A.; Joly, F.X.; Santoja, M.; Fromin, N. Changes in soil microbial substrate utilization in response to altered litter diversity and precipitation in a Mediterranean shrubland. Biol. Fertil. Soils 2017, 53, 171-185. [CrossRef]

242. Jucker, T.; Bouriaud, O.; Avacaritei, D.; Dänila, I.; Duduman, G.; Valladares, F.; Coomes, D.A. Competition for light and wàter play contrastin roles in driving diversity-productivity relationships in Iberian forest. J. Ecol. 2014, 102, 1202-1213. [CrossRef]

243. Vourlitis, G.L. Chronic N enrichment and drought alter plant cover and community composition in a Mediterranean-type semi-arid shrubland. Oecologia 2017, 184, 267-277. [CrossRef] [PubMed]

244. Ariño, A.H.; Gimeno, B.S.; Pérez de Zabalza, A.; Ibañez, R.; Ederra, A.; Santamaria, J.M. Influence of nitrogen deposition on plant biodiversity at Natura 2000 sites in Spain. In Nitrogen Deposition and Natura 2000; Hicks, W.K., Whitfield, C.P., Bealey, W.J., Sutton, M.A., Eds.; European Cooperation in Science\&Technology (COST): Brussels, Belgium, 2011; pp. 140-146. 
245. Sterenberg, M.; Golodets, C.; Gutman, M.; Perevolotsky, A.; Kigel, J.; Henkin, Z. No precipitation legacy effects on above-ground net primary production and species diversity in grazed Mediterranean grassland: A 21-year experiment. J. Veg. Sci. 2017, 28, 260-269. [CrossRef]

246. Thiel, D.; Kreyling, J.; Backhaus, S.; Beierkuhnlein, C.; Buhk, C.; Egen, K.; Huber, G.; Konnert, M.; Nagy, L.; Jentsch, A. Different reactions of central and marginal provenances of Fagus sylvatica to experimental drought. Eur. J. For. Res. 2014, 133, 247-260. [CrossRef]

247. Delmotte, S.; Couderc, V.; Mouret, J.C.; López-Ridaura, S.; Barbier, J.M.; Hossard, L. From stakeholders narratives to modelling plausible future agricultural Systems. Integrated assessment of scenarios for Camargue, Southern France. Eur. J. Agron. 2017, 82, 292-307. [CrossRef]

248. Granados, M.E.; Vilagrosa, A.; Chirino, E.; Vallejo, V.R. Reforestation with resprouter species to increase diversity and resilence in Mediterranean pine forests. For. Ecol. Manag. 2016, 362, 231-240. [CrossRef]

249. De Dato, G.D.; Loperfido, L.; De Angelis, P.; Valentini, R. Establishment of a field with Mediterranean shrubs in Sardinia and its evaluation for climate mitigation and to combat desertification in semi-arid regions. iForest 2009, 2, 77-84. [CrossRef]

250. Chirino, E.; Bonet, A.; Bellot, J.; Sánchez, J.R. Effects of 30-year-old Aleppo pine plantations on runoff, soil erosion, and plant diversity in a semi-arid landscape in south eastern Spain. Catena 2006, 65, 19-29. [CrossRef]

251. Ribeiro, S.; Fernandes, J.P.; Espírito-Santo, M.D. Diversity and florístic patterns of Mediterranean grassland: The relative influence of environmental and land management factors. Biodivers. Conserv. 2014, 23, $2903-2931$. [CrossRef]

252. Stavi, I. Biochar use in forestry and tree-based agro-ecosystems for increasing climate change mitigation and adaptation. Int. J. Sustain. Dev. World Ecol. 2013, 20, 166-181. [CrossRef]

253. Leiva, M.J.; Mancilla-Leyton, J.M.; Martín-Vicente, A. Methods to improve the recruitment of holm oak seedlings in grazed Mediterranean savanna-like ecosystems (dehesas). Ann. For. Sci. 2013, 70, 11-20. [CrossRef]

254. Vizzarri, M.; Tognetti, R.; Marchetti, M. Forest Ecosystem services: Issues and challenges for biodiversity, conservation, and Management in Italy. Forest 2015, 6, 1810-1838. [CrossRef]

255. Koniac, G.; Noy-Meir, I.; Perevolotsky, A. Modeling Dynamics of ecosystem services Basket in Mediterranean landscapes: A tool for rational management. Landsc. Ecol. 2011, 26, 109-124. [CrossRef]

256. Vizzarri, M.; Sallustio, L.; Travaglini, D.; Bottalico, F.; Chirici, G.; Garfi, V.; Lafortezza, R.; La Mela Beca, D.S.; Lombardi, F.; Maetzke, F.; et al. The MIMOSE approach to suppiort sustainable forest management Planning at regional scale in Mediterranean contexts. Sustainability 2017, 9, 316. [CrossRef]

257. Chornesky, E.A.; Ackerly, D.D.; Beier, P.; Davis, F.W.; Flint, L.E.; Lawler, J.J.; Moyle, P.B.; Moritz, M.A.; Scoonover, M.; Byrd, K.; et al. Adapting California's ecosystems to a changing climate. BioScience 2015, 65, 247-262. [CrossRef]

258. Almagro, M.; de Vicente, J.; Boix-Fayos, C.; García-Franco, N.; Melogares de Aguilar, J.; Gonazález, D.; Solé-Benet, A.; Martínez-Mena, M. Sustainable land management practices as providerrs of several ecosystem services under rainfed Mediterranean egroecosystems. Mitig. Adapt. Strateg. Glob. 2016, 21, 1029-1043. [CrossRef]

259. Carvalho-Santos, C.; Sousa-Silva, R.; Gonçalves, J.; Pradinho Honrado, J. Ecosystem services and biodiversity conservation under forestation scenarios: Options to improve management in the Vez watershed, NW Portugal. Reg. Environ. Chang. 2016, 16, 1557-1570. [CrossRef]

260. Prisco, I.; Carboni, M.; Jucker, T.; Acosta, A.T.R. Temporal changes in the vegetation of Italian coastal dunes: Identification winners and losers through the lens of funcional traïts. J. Appl. Ecol. 2016, 53, 1533-1542. [CrossRef]

261. Palomo, I.; Martín-López, B.; Zorrilla-Miras, P.; García Del Amo, D.; Montes, C. Deliberative mapping of ecosystem services within and around Doñana National Park (SW Spain) in relation to land use change. Reg. Environ. Chang. 2014, 14, 237-251. [CrossRef]

262. Marañón-Jiménez, S.; Castro, J. Effect of decomposing post-fire coarse woody debris on soil fertility and nutrient availability in a Mediterranean ecosystem. Biogeochemistry 2013, 112, 519-535. [CrossRef]

263. Maroto, C.; Segura, M.; Ginestar, C.; Uriol, J.; Segura, B. Sustainable forest management in a Mediterranean region: Social preferences. For. Syst. 2013, 22, 546-558. [CrossRef] 
264. Quintas-Soriano, C.; Castro, A.J.; Castro, H.; García-Llorente, M. Impacts of land use change on ecosystem services and implicationsfor human well-being in Spanish drylands. Land Use Policy 2016, 54, 534-548. [CrossRef]

265. García-Llorente, M.; Martín-López, B.; Nunes, P.A.L.D.; González, J.A.; Alcorlo, P.; Montes, C. Analyzing the social factors that influence willingness to pay for invasive alien species management under two diferent strategies: Eradication and prevention. Environ. Manag. 2011, 48, 418-435. [CrossRef] [PubMed]

266. Fleischer, A.; Sternberg, M. The econòmic impact of global change on Mediterranean rangeland ecosystems: A space-for-time approach. Ecol. Econ. 2006, 59, 287-295. [CrossRef]

267. Lafortezza, R.; Sanesi, G.; Chen, J. Large-scale effects of forest management in Mediterranean landscape of Europe. iForest 2013, 6, 342-346. [CrossRef]

(C) 2017 by the authors. Licensee MDPI, Basel, Switzerland. This article is an open access article distributed under the terms and conditions of the Creative Commons Attribution (CC BY) license (http:/ / creativecommons.org/licenses/by/4.0/). 